\title{
What are the unmet supportive care needs of men affected by penile cancer? A systematic review of the empirical evidence.
}

PATERSON, C., PRIMEAU, C., BOWKER, M., JENSEN, B., MACLENNAN, S., YUAN, Y. and N'DOW, J. 


\section{Introduction}

Globally, penile cancer is an uncommon malignancy with reported incidence of 0.84 cases per 100,000 in globally (Sewell et al., 2015, Cardona and García-Perdomo, 2018). In contrast, the incidence is significantly higher in developing countries that are affected by economic disparity such as Brazil, India and African nations who have the highest reported incidence with rates as high as $6 \%$ of malignant neoplasms (Vieira et al., 2020). Penile cancer affects men over 18 years of age with the mean age of 55 years at the time of diagnosis. There is a range of treatment modalities for penile cancer depending on the stage of disease. The primary treatment for penile cancer is surgery, although in the case of precancerous changes or early stage malignancies, minimally invasive treatments such as topical chemotherapy with imiquimod or 5-fluorouracil (5-FU), laser therapy or brachytherapy may be applicable (Hakenberg et al., 2018). Surgical treatment involves the removal of the primary tumour lesion with or without performing inguinal and pelvic lymphadenectomy, depending on clinical indications or the histopathology. Surgical intervention includes the resection of the primary lesion by circumcision, glansectomy, a partial penectomy or a total penectomy amputation of the penis, (Hakenberg et al., 2018).

All treatments can be disfiguring and can have a profound negative impact on the patient's sexual function, quality of life (QOL), social interactions, self-image and self-esteem (Maddineni et al., 2009). Different modalities of treatment are associated with their own individual challenges for patients, complications, unique psychological burden, and unmet supportive care needs (Leem and Klaassen, 2018). A recent qualitative study identified that men and their loved ones affected by penile cancer can grapple with a range of needs which were inadequately addressed in routine care delivery with their urologist. Some men articulated that they had suicidal feelings following surgery, marital problems, sexual concerns, and practical issues around changes with urination (Gordon et al., 2017). Supportive care is defined as a person-centered approach to the provision of the necessary services for those living with or affected by cancer to meet their informational, spiritual, emotional, social, or physical needs during diagnosis, treatment, or follow-up phases including issues of health promotion and prevention, survivorship, palliation and bereavement (Paterson et al., 2018). Little is known about the unmet supportive care needs experienced by patients and their loved ones affected by penile cancer, and the areas in which they most require assistance (Bullen et al., 2009). Individual supportive care needs can be classified into eleven primary domains of need (Paterson et al., 2015, Paterson et al., 2018) based upon domains of need in the literature (Maddineni et al., 2009) and clinical expertise. Specifically, the domains include physical, psychosocial/emotional, family-related, social, interpersonal/intimacy, practical, daily living, spiritual/existential, health system/information, 
patient-clinician communication, and cognitive needs. The classification of supportive care needs domains are informed by the Supportive Care Needs Framework (Aranda and Yates, 2009). See Table 1 for supportive care needs classification.

An existing systematic review (Maddineni et al., 2009), identified that $50 \%$ of men affected by penile cancer experienced psychological problems, $40 \%$ reported a negative impact on quality of life, and $70 \%$ of patients experienced difficulties with sexual function. Their review included only 128 patients, from 6 studies, of which 5 studies contained retrospective data and one study collected prospective data on erectile function only. This review does not identify the lived experienced of penile cancer, the impact that penile cancer can have on loved ones, or, importantly, the areas of unmet supportive care needs in care delivery. Gaining more knowledge of the experiences of men and their loved ones affected by penile cancer will provide important insights for healthcare providers to create a holistic model of care and clinical practice guidelines. Therefore, this systematic review will address the following clinically focused research questions:

1. What are the different domains of unmet supportive care needs of men and their loved ones affected by penile cancer?

2. What are the most frequently reported individual domains of unmet need in the current available literature?

\section{Methods}

This review was conducted using the systematic review methodology recommended by the European Association of Urology (Knoll et al., 2018) for clinical guidelines practice and the Preferred Reporting for Systematic Reviews (Moher et al., 2009). We published our review protocol in the International Prospective Register of Systematic Reviews, Prospero, available from: http://www.crd.york.ac.uk/PROSPERO/display record.php?ID=CRD42018102376.

\section{Eligibility Criteria}

\section{Types of studies}

- We included qualitative and quantitative methods irrespective of research design.

- We excluded case reports, commentaries, editorials, and studies where unmet supportive care needs were not reported. 
Types of participants

- We included adult men ( $\geq 18$ years of age) with a confirmed histological diagnosis of penile cancer and their partners.

- All stages of disease and treatment modalities were included

- We excluded studies conducted with patients with mixed cancer groups, except when a separate sub-group analyses of only penile cancer patients were reported.

Types of Outcomes measures

The primary outcome of this review was non-oncological outcomes related to:

- Unmet supportive care needs (e.g. the Supportive Care Needs Survey (Boyes et al., 2009) and qualitative experiences.

\section{Literature Search}

The CINAHL, MEDLINE, PsychINFO, Embase, Cochrane Central Register of Controlled Trials (CCTR) and the Cochrane Database of Systematic Reviews (CDSR) databases and clinicaltrial.gov were searched for all relevant publications (date cut off 1990 to April 2020, limited to English language). Key words (penis cancer, penile neoplasms, unmet needs, health care need, patient care, psychological assessment) were mapped to each electronic database using the appropriate MeSH term, or used free search terms. The search architecture used a wide range of keywords and free text items to increase the sensitivity and specificity of the searches (see Supplementary file 1). Additional searches were performed in Index to Theses, Google Scholar, and Google. The references of relevant systematic reviews and original articles included in this current review were screened for studies potentially meeting our inclusion criteria.

\section{Data collection and analysis}

\section{Selection of studies}

Following de-duplication, four review authors (MB, BJ, $\mathrm{CP}, \mathrm{CP})$ independently screened the titles and abstracts of the identified records for eligibility. The full text of all potentially eligible records were retrieved and screened independently by the four reviewers using a standardised form, linking 
together multiple records of the same study in the process. Any disagreements were resolved by discussion.

Data extraction and management

All four review authors (CP, CP, MB, BJ) independently extracted the outcome data and compared for accuracy. Any disagreements were resolved by discussion. A standardised data extraction form was developed and piloted among the reviewers prior to its use. The extracted data included 'characteristics of included studies' (study design; countries and institutions where the data were collected; participant demographic and clinical characteristics, unmet supportive care needs; the numbers of participants who were included in the study; losses and exclusions of participants, with reasons).

\section{Assessment of risk of bias in included studies}

Quality assessment of individual research studies were undertaken using two quality appraisal tools, one for studies reporting qualitative data (Shaw et al., 2009) and one for studies reporting quantitative data and have been used in a series of reviews. These tools were developed as part of a Health Technology Assessment Integrative Review (Shaw et al., 2009) and have been used in previous cancer care systematic integrative review publications (Paterson et al., 2018, Paterson et al., 2015). The quantitative appraisal tool assessed a range of designs including: RCT's, non-randomized controlled studies, cohort, case-control, other observational studies (for example, interrupted time series, case series, cross-sectional designs) and were classified as "low", "unclear" and "high" risk according to the criteria specific to each study design. Some items in the quantitative assessment tool are only relevant to RCT's; therefore a "non-applicable" item option was available for other research designs. The qualitative appraisal tool has 15 items and three levels of quality assessment ranging from two to zero (see supplementary Tables 2 ).

\section{Data synthesis}

We used narrative synthesis approach to summarise the evidence. This involved tabulation of primary research studies, identifying similarities and differences within and between studies, and seeking explanations for these differences (Centre for Reviews and Dissemination, 2009). We undertook the following steps: data reduction and sub-group classification based on levels of evidence (Department of Health, 2001) and the review questions, narrative data comparison (iterative process of making comparisons and identifying relationships) and finally, drawing conclusions (Whittemore and Knafl, 2005). The level of evidence was categorised by typologies of supporting evidence identified by the 
Department of Health in the National Service Framework, United Kingdom see Table 2 (Department of Health, 2001).

\section{Results}

Search Results

Of the 1725 retrieved from the search, 1662 articles were excluded following the application of the inclusion and exclusion criteria during the title and abstract screening, see Figure 1. In total, 62 fulltext publications were reviewed in full and 45 were excluded with reasons and 18 articles were included, reporting the results from 17 studies in the final review (Kieffer et al., 2014, Soh et al., 2014, Sosnowski et al., 2016, Wan et al., 2018, Windahl et al., 2004, Witty et al., 2013, Mortensen and Jakobsen, 2013, Skeppner and Fugl-Meyer, 2015, Skeppner et al., 2008, Opjordsmoen et al., 1994, Bhat et al., 2018, Bullen et al., 2010, Drager et al., 2017, Delaunay et al., 2014, Ficarra et al., 2000, Gordon et al., 2017, Bullen et al., 2009, D'Ancona et al., 1997, Bullen et al., 2010, Bullen et al., 2009). There was a range of study designs across the 17 included studies which underscores that this is a developing evidence base and these included: qualitative (n7) and survey (n10), see Table 3 . The studies were conducted in a range of countries namely: Brazil (n1), India (n1), United Kingdom (n2), Germany (n1), France (n1), France/Spain (n1), Italy (n1), USA (n1), Denmark (n2), Norway (n1), Sweden (n3), Poland (n1), and China (n1). The sample sizes varied from n4 to n90 with a total sample size of n469 across the studies. Most of the participants in the included studies were married, over 50 years of age, and received heterogeneous therapies from minimally invasive therapy to total penectomy, see supplementary Table 3.

\section{Quality Appraisal}

The methodological quality assessment of the primary studies was conducted in parallel with the data extraction, Table 4. There are a number of shortcomings across the studies which included small sample sizes (Drager et al., 2017, Delaunay et al., 2014, Ficarra et al., 2000, Opjordsmoen et al., 1994, Sosnowski et al., 2016, Wan et al., 2018) lack of transparency in qualitative methodology (Mortensen and Jakobsen, 2013, Bhat et al., 2018, Ficarra et al., 2000) and limited reporting of the clinical and demographic characteristics across the study participants.

\section{Frequency of supportive care needs documented in the literature}

In descending order of the frequency of supportive care needs reported in the reviewed studies: intimacy/interpersonal needs (16/17), psychological emotional needs (14/17), physical needs $(12 / 17)$, family related needs (7/17), health system information needs (7/17), social needs (5/17), daily living 
needs (3/17), patient/clinician communication (3/17), spiritual needs (3/17), practical needs $(2 / 17)$, see Table 5.

\section{Evidence of Unmet Supportive Care Needs by Domain}

Men reported that the impact of penile cancer surgery affected physical, psychological, and sexual well-being with each facet impacting and being intertwined with the other at varying degrees. Thus, indicating the complexity of needs for men pre-surgery, during post-surgical care and into survivorship. The results are structured by the domains used in the supportive care needs classification (outlined in Table 6).

\section{Interpersonal/Intimacy Needs}

The devastating impact that a new diagnosis of penile cancer and related treatments was identified as a clinically significant theme across many of the studies related to unmet intimacy needs. Several studies identified that participants reported that their relationship with their partners was affected by sexual dissatisfaction (Bhat et al., 2018, Delaunay et al., 2014, Ficarra et al., 2000, Skeppner and FuglMeyer, 2015, Skeppner et al., 2008, Sosnowski et al., 2016, Wan et al., 2018). Moreover, in one study, $90 \%$ of the participants experienced anxiety in relation to their sexual performance (Bhat et al., 2018). Concerns about sexual performance affected both married and single men. Married men expressed long term concerns about satisfying their partners (Witty et al., 2013), and unmarried men avoided new relationships out of fear of ridicule, rejection (Bullen et al., 2010, Bullen et al., 2009) and perceptions that the scar would repulse women (Bullen et al., 2010, Bullen et al., 2009, Mortensen and Jakobsen, 2013). Studies illuminated frustrations due to an inability to achieve orgasm (Bullen et al., 2010, Bullen et al., 2009), which for some resulted in marital problems (Gordon et al., 2017, Opjordsmoen et al., 1994). Due to inevitable consequences of total penectomy, men expressed that they felt deprived of a sex life and considered this to be an aspect of life that is genuine and very natural (Gordon et al., 2017). Furthermore, sexual urges after total penectomy contributed to a disconnect between the sensory self and the physical self for some men (Witty et al., 2013). Men reported sexual distress in multiple areas related to sexual interest, quality of erections, early ejaculation and dyspareunia which was persistent following treatment (Windahl et al., 2004). Despite a range of complex concerns and sexual needs for men and their loved ones following treatment, little or no support was provided in care delivery in some of the narratives (Bullen et al., 2010, Bullen et al., 2009).

$\underline{\text { Psychological/Emotional Needs }}$ 
The profound psychological impact of penile cancer and its associated treatments was evident across most (14/17) of the included studies. Men articulated concerns related to their ability to disclose their penile cancer diagnosis to family and friends (Gordon et al., 2017) due to feelings of embarrassment. Patients experienced difficulties in coping with the fear of dying (D'Ancona et al., 1997), the impact of mutilation and associated lack of sexual pleasure (D'Ancona et al., 1997), altered perceptions of masculinity (Bhat et al., 2018, Bullen et al., 2010, Bullen et al., 2009, Mortensen and Jakobsen, 2013), embarrassment and stigma (Bullen et al., 2010, Bullen et al., 2009, Gordon et al., 2017), altered body image (Kieffer et al., 2014), feelings of sorrow, anxiety and sadness (Drager et al., 2017, Gordon et al., 2017, Skeppner et al., 2008, Witty et al., 2013), shock (Gordon et al., 2017), fear (Gordon et al., 2017), denial (Gordon et al., 2017) and reduced self-esteem (Sosnowski et al., 2016). One study identified that some men developed panic attacks which manifested in stomach aches and breathing difficulties (Mortensen and Jakobsen, 2013). Other men experienced social phobia and post-traumatic stress disorders with subsequent alcohol abuse (Opjordsmoen et al., 1994). Major depression was associated with complete sexual dysfunction for some men (Opjordsmoen et al., 1994, Windahl et al., 2004). Men articulated fear related to the physical scar which made them worry that their cancer had returned (Witty et al., 2013). Across several studies patients reported feeling very scared and experienced multiple episodes of feeling suicidal (Gordon et al., 2017), anxiety and depression with the need for psychosocial interventions but they did not receive any help or the necessary referrals (Drager et al., 2017, Ficarra et al., 2000, Mortensen and Jakobsen, 2013, Witty et al., 2013). Moreover, loved ones also reported being at risk of anxiety at the time of their partners diagnosis and into the survivorship journey (12 months later) (Skeppner and Fugl-Meyer, 2015) suggesting the need for appropriate on-going support as a couple. The need for psychosocial interventions for couples was echoed elsewhere as men talked about grappling with severe mood swings which was damaging and had a negative impact on their relationship with their partners (Witty et al., 2013). Finally, men reported a lack of information prior to surgery which affected their emotional well-being post treatment and beyond (Witty et al., 2013).

\section{Physical Needs}

The physical impact of treatment varied considerably across the included studies. Twelve studies (Bullen et al., 2009, D'Ancona et al., 1997, Delaunay et al., 2014, Drager et al., 2017, Ficarra et al., 2000, Gordon et al., 2017, Kieffer et al., 2014, Mortensen and Jakobsen, 2013, Skeppner and FuglMeyer, 2015, Sosnowski et al., 2016, Wan et al., 2018, Witty et al., 2013), identified the unmet physical needs of men affected by penile cancer. The physical difficulties were far ranging and included: discomfort and difficulties urinating (D'Ancona et al., 1997, Drager et al., 2017, Gordon et al., 2017, 
Kieffer et al., 2014, Mortensen and Jakobsen, 2013, Wan et al., 2018, Witty et al., 2013) problems with sleeping and reduced physical strength (Bullen et al., 2010, Bullen et al., 2009), limitations in mobility (Drager et al., 2017, Witty et al., 2013), genital pain (Delaunay et al., 2014, Drager et al., 2017, Mortensen and Jakobsen, 2013, Skeppner and Fugl-Meyer, 2015), exhaustion (Drager et al., 2017, Witty et al., 2013), changes in sensation of the penile gland (Delaunay et al., 2014, Skeppner and FuglMeyer, 2015), altered penile appearance (Delaunay et al., 2014), frequent bleeding and meatal stenosis (Delaunay et al., 2014), reduced general state of health (Ficarra et al., 2000, Mortensen and Jakobsen, 2013, Sosnowski et al., 2016), penile swelling and itching (Gordon et al., 2017), erectile dysfunction (Gordon et al., 2017), retarded ejaculation/anejaculation (Skeppner and Fugl-Meyer, 2015), concerns related to lymphoedema due to lymph node dissection (Witty et al., 2013) and postsurgical infections which inhibited men from moving on emotionally and physically (Witty et al., 2013).

\section{Family Related Needs}

The impact of penile cancer had a profound negative impact on the family unit. Concerns were shared across several studies related to young men who were diagnosed with penile cancer and the implications for having children (Bullen et al., 2010, Bullen et al., 2009, Mortensen and Jakobsen, 2013). Other men spoke about the difficulties in maintaining their role as a husband, lover and father. In one study, the partners articulated their own unmet needs in coping with their husband's diagnosis (Gordon et al., 2017) and suggested that partners needs were not being addressed in care provision. Evidence has acknowledged that penile cancer profoundly affected the dyadic processes of couples' adjustment and related communication together (Skeppner and Fugl-Meyer, 2015). Some individuals experienced communication breakdown, and martial crisis after treatment (Opjordsmoen et al., 1994). Some men subsequently divorced due to problems after therapy (Opjordsmoen et al., 1994), but other contextual factors which might have affected marriage breakdown for these couples were not clear. Elsewhere, wives of men affected by penile cancer "understood and accepted" sexual dysfunction as an inevitable consequence of treatment (Soh et al., 2014). Moreover, men viewed the support from their wives as an important factor with coping with the impact of surgery (Witty et al., 2013).

\section{Health System/Information Needs}

A central theme resonated in relation to inadequate informational support and provision. Men articulated that they felt "poorly informed" in relation to the consequence of treatment on quality of life, sexuality, with a general lack of information across the cancer trajectory (Delaunay et al., 2014, Witty et al., 2013). Patients shared their concerns and frustrations regarding a perceived lack of the doctor's knowledge and ability to provide a timely and accurate cancer diagnosis, as some men were 
misdiagnosed for many months (Gordon et al., 2017, Mortensen and Jakobsen, 2013). Others described a fragmented care pathway with little or no access to supportive care or rehabilitation (Mortensen and Jakobsen, 2013) within their healthcare system (Gordon et al., 2017). Other challenges were in relation to public health and the need to raise the profile of awareness of the early signs and symptoms of penile cancer. Some men delayed seeking medical attention by one-and-ahalf years to two years due to a lack of knowledge and feelings of embarrassment (Mortensen and Jakobsen, 2013, Skeppner et al., 2008). Men articulated that they would have benefited greatly from counselling and psychosocial services within their healthcare system, but these were never offered (Witty et al., 2013).

\section{$\underline{\text { Social Needs }}$}

Men voiced a reduced level of social functioning (Sosnowski et al., 2016). Following treatment some men experienced low confidence levels and struggling to interact with others in social circles (Witty et al., 2013). The impact of an altered body image inhibited some men participating in social activities which involved wearing shorts due to the belief that they perceived the public would see that they have had a penectomy (Witty et al., 2013). Some other men's narratives indicated that they needed access to cubicles to sit to urinate, and urination was helped by aids such as funnels (Witty et al., 2013).

\section{Daily Living Needs}

Men experienced a restriction on their daily lives when out in public due to urination challenges post treatment (Bullen et al., 2010, Bullen et al., 2009, Kieffer et al., 2014, Witty et al., 2013). Men needed public access to disabled toilets when away from home (Witty et al., 2013, Bullen et al., 2010, Bullen et al., 2009) which was problematic at times. Men also articulated daily living concerns due to inability to work and remain the status of the "breadwinner" (Bullen et al., 2010, Bullen et al., 2009).

\section{$\underline{\text { Patient-Clinician Information Needs }}$}

Across the included studies several highlighted critical short-comings and limitations in routine service delivery in relation to support, information and access to rehabilitation (Bullen et al., 2010, Bullen et al., 2009, Witty et al., 2013). Men articulated a lack of self-management advice from healthcare professionals in relation to sexuality and learning to cope with new ways of urination post-treatment (Bullen et al., 2010, Bullen et al., 2009). Noteworthy, across all the studies none of the participants referred to having access to specialist nurses at diagnosis, during treatment or into survivorship. Furthermore, some men reported a lack of person-centered care with a lack of trust and compassion 
from their treating clinician (Gordon et al., 2017). This illuminates some fundamental elements of care provision that needs addressing in clinical practice to improve patient care and experience.

\section{Spiritual Needs}

Men experienced existential threat (Mortensen and Jakobsen, 2013) accompanied by feelings of shock, disbelief, fear and disappear (Bullen et al., 2010, Bullen et al., 2009). The diagnosis of penile cancer and its associated treatments (Gordon et al., 2017) challenged men's' manhood with multiple accounts of suicidal ideation. Several men expressed to have lost faith at some point during the sickness trajectory (Gordon et al., 2017).

\section{Practical Needs}

Following treatment men reported practical needs related to urination and mobility (Bullen et al., 2010, Bullen et al., 2009, Witty et al., 2013). Men reported that urination was helped by using aids, such as funnels, re-training themselves in self-management behaviours, including sitting down to urinate and accessing a cubical. These strategies were important to reduce spraying and dribbling of urine down their legs.

\section{Cognitive Needs}

None of the included studies provided accounts of cognitive needs of men affected by penile cancer.

\section{Partners}

Across the included studies only two studies included partners (Bhat et al., 2018, Skeppner and FuglMeyer, 2015) which limits understanding of the unmet supportive care need domains from the partners perspective. Bhat and colleagues identified that in all patients the relationship with their partners was affected by sexual dissatisfaction with $90 \%$ of the men reported anxiety about their sexual performance. Moreover, partners reported being at risk of anxiety at the time of their partners diagnosis and into the survivorship journey (12 months later) (Skeppner and Fugl-Meyer, 2015) suggesting the need for appropriate on-going support as a couple. Cancer affected the dyadic processes of the couple's adjustment and reduced communication together (Skeppner and FuglMeyer, 2015). Moreover, where partners accompanied the men during their interviews, they expressed their need to share their own perspectives on the experience of penile cancer but these accounts were not reported (Gordon et al., 2017). 


\section{Discussion}

The rarity of penile cancer represents a significant challenge to the patient, partner and healthcare professional, at each step along the cancer care continuum, from diagnosis to treatment and into survivorship. Undisputedly, given the severity of treatment options and associated consequences of urinary and sexual dysfunction, coupled with psychological effects and altered perceptions of masculinity, identifying the unmet supportive care needs of patients and their loved ones affected by penile cancer is paramount to inform service delivery. This systematic review has made an important clinical contribution by informing multidisciplinary healthcare professionals about the complex person-centred supportive care needs in this relatively small patient population.

The problems for men and their partners affected by penile cancer were diverse and complex which requires a sensitive and compassionate approach to the provision of necessary services. Many men shared in their narratives that they "sat" on their symptoms for many months, if not years, before seeking medical attention due to a lack of general knowledge about the early signs and symptoms of penile cancer, and feelings of embarrassment. Some men also shared their frustrations and anger that they had been misdiagnosed, or outright dismissed, by medical staff which led to a delay in receiving their cancer diagnosis and subsequent treatment. Penile cancer is a rare condition that very few healthcare professionals will ever encounter excluding the Urologists or healthcare professionals based in supra-regional centres (Vanthoor et al., 2019). Therefore, greater attention is needed to raise the profile of this condition. We can learn from the successful strategies from our prostate and breast cancer campaigners historically.

This systematic review of the unmet needs of men and their loved ones affected by penile cancer, not unsurprisingly, revealed a profound negative psychological impact and a lack of support provided to them in care provision. Distress was experienced along a continuum ranging from normal feelings of vulnerability, sadness and fear because of a cancer diagnosis, to overwhelming episodes of suicidal tendencies, deep depression and anxiety in several other studies. Evidence has clearly identified that coping strategies can help to manage the psychological and physical stressors associated with cancer and treatment (Paterson et al., 2013). Broadly, coping is defined as cognitive and/or behavioural attempts to manage situations that are appraised as stressful to an individual. The transactional process of stress and coping theory (Folkman and Lazarus, 1984) details the central importance of support (informational, emotional, practical) on improving quality of life outcomes for people affected by cancer. Based on the findings of this systematic review, there is a notable lack of literature 
investigating whether support (informational, emotional and practical) moderates or mediates the relationship between coping and distress for men affected by penile cancer. Future studies should also examine predictor variables such as education, socio-economic status, employment, and clinical variables across various coping strategies to help stratify those at risk of distress. This review has demonstrated that couples affected by penile cancer are required to cope and adjust in every aspect of their lives. Given the under-recognition of psychological needs of men and their partners, we recommend the routine use of patient-reported Holistic Need Assessments (Biddle et al., 2016) in clinical practice to identify patients at risk to enable "timely referrals" for psychosocial care. Successful integration of standardized and validated holistic needs assessments has been well established in other tumor groups, including other urological cancers (Howell et al., 2015, Primeau et al., 2017).

Of all the urogenital cancers, the one that most obviously jeopardizes sexual function is penile cancer. Several studies identified that healthcare providers failed to initiate conversations about the impact of treatment on sexuality and relationships, rehabilitation and "individual identities". Developing survivorship care programs to address areas of unmet needs might incorporate existing theoretical concepts of masculinity (Alexis and Worsley, 2018) to support men to adapt and re-construct their own ideas of self and sexuality. Masculinity was a prominent theme in the patient voices across the included studies. Moreover, we recommend a multidisciplinary follow-up with psychologists trained in sex therapy to be considered in the prehabilitation phase of treatment decision-making to help patients and their partners to discuss their feelings around intimacy and sexual well-being. The clinical need for developing shared interventions for couples was evidenced in this systematic review, but of note, only two studies (Bhat et al., 2018, Skeppner and Fugl-Meyer, 2015) included partners. In $21^{\text {st }}$ century healthcare, we acknowledge that cancer not only affects the person who is diagnosed with cancer but also their family/loved ones (Berg and Upchurch, 2007). Thus, future research is needed to further explore the needs and preferences for support from the partners' perspective. Moreover, men's and their partners' narratives identified that they experienced shock from seeing the results of the surgery which results in a negative impact on sexual well-being. We therefore need to develop and evaluate pre-surgical interventions and patient counselling to foster realistic expectations for the couple about recovery and the impact on broader aspects of quality of life. Currently there is no penile cancer specific quality of life (QOL) instrument with demonstrated reliability and validity to assess changes in QOL over time. Therefore, a further recommendation is that future research should focus on developing an instrument for research and clinical use in practice.

\section{Limitations}


One of the major challenges of this review was combining heterogeneous study designs and methodologies, and our findings are constrained due to the methodological limitations of the primary studies included. We excluded case reports as defined as a singular report on one individual patient which might have missed experiential accounts in the literature. Furthermore, we included qualitative and quantitative studies to elicit how unmet needs were expressed by the participants without being necessarily assessed as a primary objective in the included studies, which may have introduced bias. We included international literature which was a strength to understand the experience of unmet supportive care needs of men and their loved one affected by penile cancer globally. Given the relatively small numbers of participants included in this review we were not able to identify any discernible trends in unmet needs internationally based on treatments types or other clinical subgroupings. Despite the limitations, the review team followed a rigorous and transparent review methodology and reporting based upon the PRIMSA to promote re-producibility. This review has enabled a broad summary of the evidence which has importantly provided some clinical practice recommendations and facilitated refinement of the future research directions.

\section{Conclusion}

This systematic review underscores the need for clinical service reconfiguration internationally to develop new approaches and standardized ways to identify and address the profound unmet supportive care needs of men and their partners affected by penile cancer. What is clear from this review is that we need interdisciplinary clinicals team (specialist nurses, psychologists, urologists, plastic surgeons and sex therapists) working together to promote a person-centered model of rehabilitative care from diagnosis and into survivorship. Future research recommendations include the need for a consensus approach given the challenges of higher quality studies in the context of rare diseases. 


\section{References}

ALEXIS, O. \& WORSLEY, A. J. 2018. A Meta-Synthesis of Qualitative Studies Exploring Men's Sense of Masculinity Post-Prostate Cancer Treatment. Cancer nursing, 41, 298-310.

ARANDA, S. \& YATES, P. 2009. Framework for supportive care [Online]. Available: http://edcan.org.au/edcan-learning-resources/supporting-resources/supportivecare/supportive-care-framework [Accessed 11.04.020].

BERG, C. A. \& UPCHURCH, R. 2007. A developmental-contextual model of couples coping with chronic illness across the adult life span. Psychol Bull, 133, 920-54.

BHAT, G. S., NELIVIGI, G., BARUDE, V. \& SHASTRY, A. 2018. Sexuality in Surgically Treated Carcinoma Penis Patients and Their Partners. The Indian journal of surgery, 80, 19-23.

BIDDLE, L., PARAMASIVAN, S., HARRIS, S., CAMPBELL, R., BRENNAN, J. \& HOLLINGWORTH, W. 2016. Patients' and clinicians' experiences of holistic needs assessment using a cancer distress thermometer and problem list: A qualitative study. European Journal of Oncology Nursing, 23, 59-65.

BOYES, A., GIRGIS, A. \& LECATHELINAIS, C. 2009. Brief assessment of adult cancer patients' perceived needs: development and validation of the 34-item Supportive Care Needs Survey (SCNSSF34). Journal of evaluation in clinical practice, 15, 602-606.

BULLEN, K., EDWARDS, S., MARKE, V. \& MATTHEWS, S. 2010. Looking past the obvious: experiences of altered masculinity in penile cancer. Psychooncology, 19, 933-40. 
BULLEN, K., MATTHEWS, S., EDWARDS, S. \& MARKE, V. 2009. Exploring men's experiences of penile cancer surgery to improve rehabilitation. Nursing times, 105, 20-24.

CARDONA, C. E. M. \& GARCÍA-PERDOMO, H. A. 2018. Incidence of penile cancer worldwide: systematic review and meta-analysis. Revista Panamericana de Salud Pública, 41, e117.

CENTRE FOR REVIEWS AND DISSEMINATION. 2009. Systematic Reviews: CRD's guidance for undertaking reviews in health care [Online]. Available: https://www.york.ac.uk/media/crd/Systematic_Reviews.pdf [Accessed 12.04.2020].

D'ANCONA, C. A. L., BOTEGA, N. J., MORAES, C. D., LAVOURA, N. D. S., SANTOS, J. K. \& NETTO, N. R. 1997. Quality of life after partial penectomy for penile carcinoma. Urology, 50, 593-596.

DELAUNAY, B., SOH, P. N., DELANNES, M., RIOU, O., MALAVAUD, B., MORENO, F., CRAVEN, J., SOULIE, M. \& HUYGHE, E. 2014. Brachytherapy for penile cancer: Efficacy and impact on sexual function. Brachytherapy, 13, 380-387.

DEPARTMENT OF HEALTH 2001. Department of Health in the National Service Framework, Typologies of Supporting Evidence. In: DEPARTMENT OF HEALTH (ed.). London.

DRAGER, D. L., PROTZEL, C. \& HAKENBERG, O. W. 2017. Identifying Psychosocial Distress and Stressors Using Distress-screening Instruments in Patients With Localized and Advanced Penile Cancer. Clin Genitourin Cancer, 15, 605-609.

FICARRA, V., RIGHETTI, R., D'AMICO, A., PILLONI, S., BALZARRO, M., SCHIAVONE, D., MALOSSINI, G. \& MOBILIO, G. 2000. General state of health and psychological well-being in patients after surgery for urological malignant neoplasms. Urol Int, 65, 130-4.

FOLKMAN, S. \& LAZARUS, R. S. 1984. Stress, appraisal, and coping, New York: Springer Publishing Company.

GORDON, H., LOBIONDO-WOOD, G. \& MALECHA, A. 2017. Penis cancer: the lived experience. Cancer nursing, 40, E30-E38.

HAKENBERG, O., COMPÉRAT, E., MINHAS, S., NECCHI, A., PROTZEL, C., N), W. \& ROBINSON, R. 2018. European Association of Urology: Penile Cancer [Online]. Available: https://uroweb.org/guideline/penile-cancer/ [Accessed 11.04.2020].

HOWELL, D., MOLLOY, S., WILKINSON, K., GREEN, E., ORCHARD, K., WANG, K. \& LIBERTY, J. 2015. Patient-reported outcomes in routine cancer clinical practice: a scoping review of use, impact on health outcomes, and implementation factors. Annals of Oncology, 26, 18461858.

KIEFFER, J. M., DJAJADININGRAT, R. S., VAN MUILEKOM, E. A., GRAAFLAND, N. M., HORENBLAS, S. \& AARONSON, N. K. 2014. Quality of life for patients treated for penile cancer. J Urol, 192, 1105-10.

KNOLL, T., OMAR, M. I., MACLENNAN, S., HERNANDEZ, V., CANFIELD, S., YUAN, Y., BRUINS, M., MARCONI, L., VAN POPPEL, H. \& N'DOW, J. 2018. Key steps in conducting systematic reviews for underpinning clinical practice guidelines: methodology of the European Association of Urology. European urology, 73, 290-300.

LEEM, S. \& KLAASSEN, Z. 2018. Identifying Psychosocial Distress and Stressors Using Distressscreening Instruments in Patients With Localized and Advanced Penile Cancer. Clinical Genitourinary Cancer, 16, e251.

MADDINENI, S. B., LAU, M. M. \& SANGAR, V. K. 2009. Identifying the needs of penile cancer sufferers: a systematic review of the quality of life, psychosexual and psychosocial literature in penile cancer. $B M C$ urology, 9,8 .

MOHER, D., LIBERATI, A., TETZLAFF, J. \& ALTMAN, D. G. 2009. Preferred reporting items for systematic reviews and meta-analyses: the PRISMA statement. Annals of internal medicine, 151, 264-269.

MORTENSEN, G. L. \& JAKOBSEN, J. K. 2013. Patient perspectives on quality of life after penile cancer. Dan Med J, 60, A4655.

OPJORDSMOEN, S., WAEHRE, H., AASS, N. \& FOSSA, S. D. 1994. Sexuality in patients treated for penile cancer: patients' experience and doctors' judgement. Br J Urol, 73, 554-60. 
PATERSON, C., JENSEN, B., JENSEN, J. \& NABI, G. 2018. Unmet informational and supportive care needs of patients with muscle invasive bladder cancer: A systematic review of the evidence. European Journal of Oncology Nursing, 35, 92-101.

PATERSON, C., JONES, M., RATTRAY, J. \& LAUDER, W. 2013. Exploring the relationship between coping, social support and health-related quality of life for prostate cancer survivors: a review of the literature. European Journal of Oncology Nursing, 17, 750-759.

PATERSON, C., ROBERTSON, A., SMITH, A. \& NABI, G. 2015. Identifying the unmet supportive care needs of men living with and beyond prostate cancer: a systematic review. European Journal of Oncology Nursing, 19, 405-418.

PRIMEAU, C., PATERSON, C. \& NABI, G. A qualitative study exploring models of supportive care in men and their partners/caregivers affected by metastatic prostate cancer. Oncology nursing forum, 2017. Oncology Nursing Society.

SEWELL, J., RANASINGHE, W., DE SILVA, D., AYRES, B., RANASINGHE, T., HOUNSOME, L., VERNE, J. \& PERSAD, R. 2015. Trends in penile cancer: a comparative study between Australia, England and Wales, and the US. Springerplus, 4, 420.

SHAW, C., MCNAMARA, R., ABRAMS, K., CANNINGS-JOHN, R. L., HOOD, K., LONGO, M., MYLES, S., O'MAHONY, M. S., ROE, B. \& WILLIAMS, K. 2009. Systematic review of respite care in the frail elderly. Health Technology Assessment, 13, 1-246.

SKEPPNER, E. \& FUGL-MEYER, K. 2015. Dyadic Aspects of Sexual Well-Being in Men with LaserTreated Penile Carcinoma. Sex Med, 3, 67-75.

SKEPPNER, E., WINDAHL, T., ANDERSSON, S. O. \& FUGL-MEYER, K. S. 2008. Treatment-seeking, aspects of sexual activity and life satisfaction in men with laser-treated penile carcinoma. Eur Urol, 54, 631-9.

SOH, P. N., DELAUNAY, B., NASR, E. B., DELANNES, M., SOULIE, M. \& HUYGHE, E. 2014. Evaluation of sexual functions and sexual behaviors after penile brachytherapy in men treated for penile carcinoma. Basic Clin Androl, 24, 13.

SOSNOWSKI, R., KULPA, M., KOSOWICZ, M., WOLSKI, J. K., KUCZKIEWICZ, O., MOSKAL, K., SZYMAŃSKI, M., KALINOWSKI, T. \& DEMKOW, T. 2016. Quality of life in penile carcinoma patients - post-total penectomy. Central European journal of urology, 69, 204-211.

VANTHOOR, J., THOMAS, A., TSAUR, I. \& ALBERSEN, M. 2019. Making surgery safer by centralization of care: impact of case load in penile cancer. World journal of urology.

VIEIRA, C. B., FEITOZA, L., PINHO, J., TEIXEIRA-JÚNIOR, A., LAGES, J., CALIXTO, J., COELHO, R., NOGUEIRA, L., CUNHA, I. \& SOARES, F. 2020. Profile of patients with penile cancer in the region with the highest worldwide incidence. Scientific Reports, 10, 1-7.

WAN, X., ZHENG, D., LIU, C., XU, H., XIE, M., ZHOU, J., YAO, H. J. \& WANG, Z. 2018. A Comparative study of two types of organ-sparing surgeries for early stage penile cancer: Wide local excision vs partial penectomy. Eur J Surg Oncol, 44, 1425-1431.

WHITTEMORE, R. \& KNAFL, K. 2005. The integrative review: updated methodology. J Adv Nurs, 52, 546-53.

WINDAHL, T., SKEPPNER, E., ANDERSSON, S. O. \& FUGL-MEYER, K. S. 2004. Sexual function and satisfaction in men after laser treatment for penile carcinoma. J Urol, 172, 648-51.

WITTY, K., BRANNEY, P., EVANS, J., BULLEN, K., WHITE, A. \& EARDLEY, I. 2013. The impact of surgical treatment for penile cancer -- patients' perspectives. Eur J Oncol Nurs, 17, 661-7. 
Table 1. Classification of the supportive care needs.

\begin{tabular}{|l|l|}
\hline Domain of need & Definition \\
\hline Physical needs & Experience of physical symptoms such as fatigue, pain, management of bladder voiding, etc. \\
\hline Psychological/emotional needs & $\begin{array}{l}\text { Experience of psychological/emotional symptoms such as anxiety, depression, worry, } \\
\text { despair, fear, etc. }\end{array}$ \\
\hline Family-related needs & Experience of fears/concerns for the family, dysfunctional relationships, etc. \\
\hline Social needs & Experience of reduced social support, social isolation, loneliness, etc. \\
\hline Interpersonal/intimacy needs & $\begin{array}{l}\text { Experience of difficulties with self-image and masculinities, reduced libido, sexual } \\
\text { dysfunction, compromised intimacy with partner, fertility, etc }\end{array}$ \\
\hline Practical needs & $\begin{array}{l}\text { Situations of transportation, out-of-hours access to healthcare, financial/economic support, } \\
\text { etc }\end{array}$ \\
\hline Daily Living needs & Experience of restriction in daily living tasks such as exercise, housekeeping, etc \\
\hline Spiritual/existential needs & Existential concerns such as fear of death, death and dying, fears regarding after life, etc \\
\hline Health system/information & $\begin{array}{l}\text { Experience of a lack of information, uncertainty of follow-up care, lack of information in } \\
\text { relation to treatment and diagnosis, etc }\end{array}$ \\
\hline Patient-clinician communication needs & $\begin{array}{l}\text { Quality of communication between patients and healthcare professionals, satisfaction with } \\
\text { care, shared decision-making, etc }\end{array}$ \\
\hline Cognitive needs & Experience of cognitive impairments, memory loss, etc. \\
\hline
\end{tabular}


Table 2. Evidence categories used by the Department of Health in the National Service Framework.

\begin{tabular}{|l|}
\hline Typologies of supporting evidence \\
A1 Systematic reviews, which include at least one randomized control trial (RCT), e.g. systematic reviews from Cochrane. \\
B1 Individual RCTs. \\
B2 Individual non-randomized, experimental/interventional studies. \\
B3 Individual well-designed non-experimental studies, controlling statistically if appropriate. Includes case control, longitudinal, cohort, matched \\
pairs or cross-sectional random sample methodologies, and well-designed qualitative studies, well-designed analytical studies including \\
secondary analysis. \\
C1 Descriptive and other research or evaluations not in B (e.g. convenience samples). \\
C2 Case studies and examples of good practice. \\
D Summary review articles and discussions of relevant literature and conference proceedings not otherwise classified.
\end{tabular}


Table 3. Overview of the included studies.

\begin{tabular}{|c|c|c|c|c|c|c|c|c|c|c|}
\hline $\begin{array}{l}\text { Author } \\
\text { and Year }\end{array}$ & Purpose & Setting & Country & \begin{tabular}{|l|} 
Sample \\
size
\end{tabular} & Sampling & $\begin{array}{l}\text { Response } \\
\text { Rate }\end{array}$ & Attrition & Design & Time points & $\begin{array}{l}\text { Data collection } \\
\text { tools }\end{array}$ \\
\hline $\begin{array}{l}\text { Bhat et } \\
\text { al. } \\
(2018)\end{array}$ & $\begin{array}{l}\text { To evaluate } \\
\text { sexuality in } \\
\text { men and } \\
\text { their } \\
\text { partners } \\
\text { affected by } \\
\text { penile } \\
\text { carcinoma }\end{array}$ & $\begin{array}{l}\text { General } \\
\text { Hospital, } \\
\text { Honovar, } \\
\text { Karnataka } \\
\text { State, } \\
\text { Rangadorai } \\
\text { Memorial } \\
\text { Hospital, } \\
\text { TSS Shripad } \\
\text { Hedge } \\
\text { Kadave } \\
\text { Institute of } \\
\text { Medical } \\
\text { Sciences } \\
\end{array}$ & India & $\begin{array}{l}\mathrm{N}=12 \\
\text { and } \\
\mathrm{N}=12 \\
\text { partners }\end{array}$ & Convenience & $\begin{array}{l}\text { Not } \\
\text { reported. }\end{array}$ & N/A & $\begin{array}{l}\text { Cross-sectional } \\
\text { survey }\end{array}$ & $\begin{array}{l}1 \text { ( } 6 \text { years } \\
\text { after the } \\
\text { surgery) }\end{array}$ & $\begin{array}{l}\text { SFQ. } \\
\text { Qualitative } \\
\text { interview } \\
\text { design is not } \\
\text { reported. }\end{array}$ \\
\hline $\begin{array}{l}\text { Bullen et } \\
\text { al. } \\
\text { (2009), } \\
\text { reportin } \\
\text { g the } \\
\text { same } \\
\text { study as } \\
\text { Bullen et } \\
\text { al., } 2010\end{array}$ & $\begin{array}{l}\text { To examine } \\
\text { the } \\
\text { experiences } \\
\text { of penile } \\
\text { surgery for } \\
\text { men } \\
\text { affected by } \\
\text { penile } \\
\text { carcinoma. }\end{array}$ & $\begin{array}{l}\text { Large } \\
\text { District } \\
\text { General } \\
\text { Hospital }\end{array}$ & $\begin{array}{l}\text { United } \\
\text { Kingdom }\end{array}$ & $N=9$ & $\begin{array}{l}\text { Purposive } \\
\text { sample }\end{array}$ & $47 \%$ & N/A & $\begin{array}{l}\text { Cross-sectional } \\
\text { qualitative }\end{array}$ & $\begin{array}{l}1 \text { ( }>18 \\
\text { months after } \\
\text { surgery and } \\
<5 \text { years } \\
\text { after } \\
\text { surgery) }\end{array}$ & $\begin{array}{l}\text { Semi- } \\
\text { structured } \\
\text { interviews } \\
\text { with 6-8 } \\
\text { questions, } \\
\text { audio taped } \\
\text { and } \\
\text { transcribed } \\
\text { verbatim }\end{array}$ \\
\hline
\end{tabular}




\begin{tabular}{|c|c|c|c|c|c|c|c|c|c|c|}
\hline $\begin{array}{l}\text { Bullen et } \\
\text { al. } \\
\text { (2009), } \\
\text { reportin } \\
\text { g the } \\
\text { same } \\
\text { study as } \\
\text { Bullen et } \\
\text { al., } 2010\end{array}$ & $\begin{array}{l}\text { To examine } \\
\text { the } \\
\text { experiences } \\
\text { of penile } \\
\text { surgery for } \\
\text { men } \\
\text { affected by } \\
\text { penile } \\
\text { carcinoma. }\end{array}$ & $\begin{array}{l}\text { Large } \\
\text { District } \\
\text { General } \\
\text { Hospital }\end{array}$ & $\begin{array}{l}\text { United } \\
\text { Kingdom }\end{array}$ & $N=9$ & $\begin{array}{l}\text { Purposive } \\
\text { sample }\end{array}$ & $47 \%$ & $\mathrm{~N} / \mathrm{A}$ & $\begin{array}{l}\text { Cross-sectional } \\
\text { qualitative }\end{array}$ & $\begin{array}{l}1 \text { (>18 } \\
\text { months after } \\
\text { surgery and } \\
<5 \text { years } \\
\text { after } \\
\text { surgery) }\end{array}$ & $\begin{array}{l}\text { Semi- } \\
\text { structured } \\
\text { interviews } \\
\text { with 6-8 } \\
\text { questions, } \\
\text { audio taped } \\
\text { and } \\
\text { transcribed } \\
\text { verbatim }\end{array}$ \\
\hline $\begin{array}{l}\text { D'Ancon } \\
\text { a et al. } \\
(1997)\end{array}$ & $\begin{array}{l}\text { To } \\
\text { investigate } \\
\text { the impact } \\
\text { of partial } \\
\text { penectomy } \\
\text { on the } \\
\text { quality of } \\
\text { life }\end{array}$ & $\begin{array}{l}\text { Universitid } \\
\text { ade } \\
\text { Estadual de } \\
\text { Campinas }\end{array}$ & Brazil & $N=14$ & Convenience & $87.5 \%$ & $\mathrm{~N} / \mathrm{A}$ & $\begin{array}{l}\text { Cross-sectional } \\
\text { survey }\end{array}$ & $\begin{array}{l}1 \text { (11.5 } \\
\text { months, } \\
\text { range 6-72 } \\
\text { months since } \\
\text { treatment) }\end{array}$ & $\begin{array}{l}\text { Semi- } \\
\text { structured } \\
\text { interview and } \\
4 \\
\text { standardized } \\
\text { questionnaire } \\
\text { S (QSFQ, SPQ, } \\
\text { GHQ-12, } \\
\text { HADS). No } \\
\text { details } \\
\text { reported for } \\
\text { the } \\
\text { qualitative } \\
\text { component. }\end{array}$ \\
\hline $\begin{array}{l}\text { Drager } \\
\text { et al. } \\
\text { (2017) }\end{array}$ & $\begin{array}{l}\text { To examine } \\
\text { psychosocial } \\
\text { distress and } \\
\text { psychosocial } \\
\text { need for } \\
\text { patients }\end{array}$ & $\begin{array}{l}\text { University } \\
\text { Hospital }\end{array}$ & Germany & $N=40$ & Convenience & $100 \%$ & $\mathrm{~N} / \mathrm{A}$ & $\begin{array}{l}\text { Cross-sectional } \\
\text { survey }\end{array}$ & $\begin{array}{l}1 \text { (prior to } \\
\text { surgery at } \\
\text { time of } \\
\text { preadmissio } \\
\text { n) }\end{array}$ & NCCN-DT, HIS \\
\hline
\end{tabular}




\begin{tabular}{|c|c|c|c|c|c|c|c|c|c|c|}
\hline & $\begin{array}{l}\text { affected by } \\
\text { penile } \\
\text { carcinoma }\end{array}$ & & & & & & & & & \\
\hline $\begin{array}{l}\text { Delauna } \\
\text { y et al., } \\
2014\end{array}$ & $\begin{array}{l}\text { To evaluate } \\
\text { the sexual } \\
\text { function and } \\
\text { behaviour } \\
\text { after } \\
\text { brachythera } \\
\text { py for penile } \\
\text { carcinoma }\end{array}$ & $\begin{array}{l}\text { Large } \\
\text { District } \\
\text { General } \\
\text { Hospital }\end{array}$ & $\begin{array}{l}\text { Spain/Fra } \\
\text { nce }\end{array}$ & $N=19$ & Convenience & $90 \%$ & N/A & $\begin{array}{l}\text { Cross-sectional } \\
\text { survey }\end{array}$ & $\begin{array}{l}1(12.8- \\
189.8 \\
\text { months after } \\
\text { treatment) }\end{array}$ & $\begin{array}{l}\text { BASIC IDEA, } \\
\text { IIEF }\end{array}$ \\
\hline $\begin{array}{l}\text { Ficarra } \\
\text { et al. } \\
(2000)\end{array}$ & $\begin{array}{l}\text { To evaluate } \\
\text { health and } \\
\text { psychologica } \\
\text { I well-being } \\
\text { in a group of } \\
155 \text { patients } \\
\text { after surgery } \\
\text { for } \\
\text { urological } \\
\text { malignant } \\
\text { neoplasms } \\
\text { (n16 penile } \\
\text { cancer data } \\
\text { reported } \\
\text { separately) }\end{array}$ & $\begin{array}{l}\text { University } \\
\text { Hospital }\end{array}$ & Italy & $N=16$ & Convenience & $\begin{array}{l}\text { Not } \\
\text { reported. }\end{array}$ & $\mathrm{N} / \mathrm{A}$ & $\begin{array}{l}\text { Cross-sectional } \\
\text { survey }\end{array}$ & $\begin{array}{l}1 \text { (average of } \\
69 \text { months } \\
\text { after } \\
\text { treatment) }\end{array}$ & $\begin{array}{l}\text { ECOG, GHQ, } \\
\text { HADS. } \\
\text { Interviews. } \\
\text { No details } \\
\text { provided on } \\
\text { the } \\
\text { qualitative } \\
\text { component } \\
\text { of the study. }\end{array}$ \\
\hline $\begin{array}{l}\text { Gordon } \\
\text { et al., } \\
2017\end{array}$ & $\begin{array}{l}\text { To explore } \\
\text { men's and } \\
\text { their family's } \\
\text { experiences } \\
\text { of } \\
\text { healthcare }\end{array}$ & $\begin{array}{l}\text { Comprehen } \\
\text { sive Cancer } \\
\text { Centre, } \\
\text { University } \\
\text { Hospital }\end{array}$ & USA & $N=13$ & $\begin{array}{l}\text { Purposive } \\
\text { Sampling }\end{array}$ & $\begin{array}{l}\text { Not } \\
\text { reported }\end{array}$ & none & $\begin{array}{l}\text { Cross-sectional } \\
\text { qualitative }\end{array}$ & $\begin{array}{l}1 \text { (>3 months } \\
\text { after } \\
\text { diagnosis) }\end{array}$ & $\begin{array}{l}\text { Face to face } \\
\text { semi- } \\
\text { structured } \\
\text { interview, } \\
45-60 \text { min. }\end{array}$ \\
\hline
\end{tabular}




\begin{tabular}{|c|c|c|c|c|c|c|c|c|c|c|}
\hline & $\begin{array}{l}\text { in the } \\
\text { context of } \\
\text { penile } \\
\text { carcinoma }\end{array}$ & & & & & & & & & \\
\hline $\begin{array}{l}\text { Kieffer } \\
\text { et al. } \\
(2014)\end{array}$ & $\begin{array}{l}\text { To evaluate } \\
\text { sexuality, } \\
\text { HRQoL and } \\
\text { concerns in } \\
\text { men } \\
\text { affected by } \\
\text { penile } \\
\text { cancer }\end{array}$ & $\begin{array}{l}1 \text { tertiary } \\
\text { cancer } \\
\text { centre }\end{array}$ & Denmark & $N=90$ & Convenience & $61 \%$ & $\mathrm{~N} / \mathrm{A}$ & $\begin{array}{l}\text { Cross-sectional } \\
\text { survey }\end{array}$ & $\begin{array}{l}1 \text { (mean time } \\
\text { since surgery } \\
3.9 \text { years, } \\
0.1-6.8 \\
\text { years) }\end{array}$ & $\begin{array}{l}\text { IIEF-15; SF- } \\
36, \text { IOC }\end{array}$ \\
\hline $\begin{array}{l}\text { Mortens } \\
\text { en and } \\
\text { Jakobse } \\
\text { n, } 2013\end{array}$ & $\begin{array}{l}\text { To explore } \\
\text { men's } \\
\text { experience } \\
\text { of penile } \\
\text { cancer. }\end{array}$ & $\begin{array}{l}3 \text { settings: } \\
\text { Hospital, } \\
\text { GP and } \\
\text { sexologists. }\end{array}$ & Denmark & $N=4$ & $\begin{array}{l}\text { Cross- } \\
\text { sectional } \\
\text { qualitative }\end{array}$ & $\begin{array}{l}\text { Not } \\
\text { reported }\end{array}$ & $\mathrm{N} / \mathrm{A}$ & $\begin{array}{l}\text { Cross-sectional } \\
\text { qualitative }\end{array}$ & $\begin{array}{l}1 \text { (within } 6 \\
\text { months of } \\
\text { treatment) }\end{array}$ & $\begin{array}{l}\text { Semi- } \\
\text { structured } \\
\text { interviews. } \\
\text { Duration of } \\
\text { the interview } \\
\text { not reported. }\end{array}$ \\
\hline $\begin{array}{l}\text { Opjords } \\
\text { moen et } \\
\text { al. } \\
(1994)\end{array}$ & $\begin{array}{l}\text { To evaluate } \\
\text { sexuality } \\
\text { after } \\
\text { treatment of } \\
\text { penile } \\
\text { cancer }\end{array}$ & $\begin{array}{l}1 \text { tertiary } \\
\text { cancer } \\
\text { centre }\end{array}$ & Norway & $N=28$ & Convenience & $93.3 \%$ & $\mathrm{~N} / \mathrm{A}$ & $\begin{array}{l}\text { Cross-sectional } \\
\text { qualitative }\end{array}$ & $\begin{array}{l}1(80,11- \\
225 \text { months } \\
\text { post } \\
\text { treatment) }\end{array}$ & $\begin{array}{l}\text { One-to-one } \\
\text { interviews } \\
\text { and the } \\
\text { following } \\
\text { questionnaire } \\
\text { s: PAIS, GHQ, } \\
\text { EORTC QLQ } \\
\text { C-30. }\end{array}$ \\
\hline $\begin{array}{l}\text { Skeppne } \\
\text { r et al., } \\
2015\end{array}$ & $\begin{array}{l}\text { To describe } \\
\text { the dyadic } \\
\text { sexual well- } \\
\text { being and } \\
\text { quality of } \\
\text { life } \\
\text { satisfaction }\end{array}$ & $\begin{array}{l}1 \text { tertiary } \\
\text { cancer } \\
\text { centre }\end{array}$ & Sweden & $\begin{array}{l}\mathrm{N}=29 \\
\text { couples } \\
\text { for all } \\
\text { three } \\
\text { interview } \\
\text { s time } \\
\text { points }\end{array}$ & Convenience & $\begin{array}{l}\text { Not } \\
\text { reported }\end{array}$ & $\begin{array}{l}83 \% \text { at } \\
\text { baseline } \\
, 71 \% \text { at } \\
\text { the end } \\
\text { of study }\end{array}$ & $\begin{array}{l}\text { Cross-sectional } \\
\text { qualitative }\end{array}$ & $\begin{array}{l}3 \text { (before } \\
\text { surgery, at } 6 \\
\text { and } 12 \\
\text { months post } \\
\text { treatment) }\end{array}$ & $\begin{array}{l}\text { Semi- } \\
\text { structured } \\
\text { Interviews. } \\
\text { LiSat-11, } \\
\text { HADS, IIEF-5. }\end{array}$ \\
\hline
\end{tabular}




\begin{tabular}{|c|c|c|c|c|c|c|c|c|c|c|}
\hline & $\begin{array}{l}\text { before and } \\
\text { one year } \\
\text { after organ- } \\
\text { sparing laser } \\
\text { treatment } \\
\text { for penile } \\
\text { carcionoma. }\end{array}$ & & & & & & & & & \\
\hline $\begin{array}{l}\text { Skeppne } \\
\text { r et al. } \\
(2008)\end{array}$ & $\begin{array}{l}\text { To describe } \\
\text { the effect of } \\
\text { laser } \\
\text { treatment } \\
\text { on sexual } \\
\text { activity and } \\
\text { life } \\
\text { satisfaction. }\end{array}$ & $\begin{array}{l}1 \text { tertiary } \\
\text { cancer } \\
\text { centre }\end{array}$ & Sweden & $N=46$ & Convenience & $79 \%$ & N/A & $\begin{array}{l}\text { Cross-sectional } \\
\text { qualitative }\end{array}$ & $\begin{array}{l}1 \text { (mean } 4.5, \\
66 \text { months to } \\
15 \text { years post } \\
\text { treatment) }\end{array}$ & $\begin{array}{l}\text { Interviews } \\
\text { (lasted } 1 \mathrm{~h} \text { ) } \\
\text { and } \\
\text { questionnaire } \\
\text { s. Unreported } \\
\text { questionnaire } \\
\text { (containing } \\
\text { questions on } \\
\text { initial } \\
\text { symptoms, } \\
\text { treatment } \\
\text { seeking, } \\
\text { sexual } \\
\text { function/dysf } \\
\text { unction and } \\
\text { sexual } \\
\text { activity) and } \\
\text { LISat-11 }\end{array}$ \\
\hline $\begin{array}{l}\text { Soh et } \\
\text { al. } \\
(2014)\end{array}$ & $\begin{array}{l}\text { To assess } \\
\text { sexual } \\
\text { function and } \\
\text { behaviours } \\
\text { of men } \\
\text { affected by } \\
\text { penile } \\
\text { cancer }\end{array}$ & $\begin{array}{l}2 \text { tertiary } \\
\text { hospitals in } \\
\text { France. }\end{array}$ & France & $\begin{array}{l}\mathrm{N}=19 \\
\text { patients } \\
\text { and } \\
\mathrm{N}=19 \\
\text { age- } \\
\text { matched } \\
\text { controls }\end{array}$ & $\begin{array}{l}\text { Pair- } \\
\text { matched } \\
\text { controls }\end{array}$ & $95 \%$ & N/A & $\begin{array}{l}\text { Cross-sectional } \\
\text { survey }\end{array}$ & $\begin{array}{l}1 \text { (survey } \\
\text { conducted } \\
2010, \text { time } \\
\text { since } \\
\text { treatment } \\
\text { not } \\
\text { reported) }\end{array}$ & $\begin{array}{l}\text { IIEF-15; } \\
\text { Questionnair } \\
\text { e developed } \\
\text { for the study } \\
\text { using the } \\
\text { BASIC IDEA } \\
\text { grid - } \\
\text { reliability and }\end{array}$ \\
\hline
\end{tabular}




\begin{tabular}{|c|c|c|c|c|c|c|c|c|c|c|}
\hline & & & & & & & & & & $\begin{array}{l}\text { validity not } \\
\text { reported. }\end{array}$ \\
\hline $\begin{array}{l}\text { Sosnows } \\
\text { ki et al., } \\
2016\end{array}$ & $\begin{array}{l}\text { To evaluate } \\
\text { sexuality, } \\
\text { HRQoL and } \\
\text { concerns of } \\
\text { men } \\
\text { affected by } \\
\text { penile } \\
\text { cancer }\end{array}$ & $\begin{array}{l}1 \text { tertiary } \\
\text { cancer } \\
\text { centre }\end{array}$ & Poland & $N=10$ & Convenience & $91 \%$ & N/A & $\begin{array}{l}\text { Cross-sectional } \\
\text { survey }\end{array}$ & $\begin{array}{l}1 \text { (16, range } \\
7-49 \text { months } \\
\text { post } \\
\text { treatment) }\end{array}$ & $\begin{array}{l}\text { EORTC-C30, } \\
\text { SES, CMNI, } \\
\text { IIEF-15, IPSS }\end{array}$ \\
\hline $\begin{array}{l}\text { Wan et } \\
\text { al. } \\
\text { (2018) }\end{array}$ & $\begin{array}{l}\text { To } \\
\text { prospectivel } \\
\text { y evaluate } \\
\text { self-esteem } \\
\text { and } \\
\text { relationships } \\
\text {, HRQoL in } \\
\text { men } \\
\text { affected by } \\
\text { penile } \\
\text { cancer }\end{array}$ & $\begin{array}{l}1 \text { tertiary } \\
\text { cancer } \\
\text { centre }\end{array}$ & China & $N=15$ & Convenience & $\begin{array}{l}\text { Not } \\
\text { reported }\end{array}$ & N/A & $\begin{array}{l}\text { Prospective } \\
\text { longitudinal } \\
\text { survey }\end{array}$ & $\begin{array}{l}2 \text { (Time } 14 \\
\text { weeks } \\
\text { before } \\
\text { surgery; } \\
\text { Time } 26 \\
\text { months after } \\
\text { surgery) }\end{array}$ & $\begin{array}{l}\text { IIEF-15, SEAR, } \\
\text { EDITS }\end{array}$ \\
\hline $\begin{array}{l}\text { Windahl } \\
\text { et al. } \\
(2004)\end{array}$ & $\begin{array}{l}\text { To explore } \\
\text { sexual } \\
\text { function, } \\
\text { satisfaction } \\
\text { and } \\
\text { cosmetic } \\
\text { results for } \\
\text { men } \\
\text { affected by } \\
\text { penile } \\
\text { cancer }\end{array}$ & $\begin{array}{l}1 \text { tertiary } \\
\text { cancer } \\
\text { centre }\end{array}$ & Sweden & $N=46$ & Convenience & $79 \%$ & N/A & $\begin{array}{l}\text { Cross-sectional } \\
\text { survey }\end{array}$ & $\begin{array}{l}1 \text { (median } 3 \\
\text { years, } 6 \\
\text { months to } 15 \\
\text { years post } \\
\text { treatment) }\end{array}$ & $\begin{array}{l}\text { IIEF, LiSat-11, } \\
\text { Questionnair } \\
\text { e Perceived } \\
\text { Cosmetic } \\
\text { Results - } \\
\text { reliability and } \\
\text { validity not } \\
\text { reported. }\end{array}$ \\
\hline
\end{tabular}




\begin{tabular}{|c|c|c|c|c|c|c|c|c|c|c|}
\hline $\begin{array}{l}\text { Witty et } \\
\text { al. } \\
(2013)\end{array}$ & $\begin{array}{l}\text { To explore } \\
\text { men's } \\
\text { experiences } \\
\text { of living with } \\
\text { penile } \\
\text { cancer. }\end{array}$ & $\begin{array}{l}9 \\
\text { multidiscipl } \\
\text { inary } \\
\text { healthcare } \\
\text { teams in } \\
\text { England } \\
\text { and Wales }\end{array}$ & $\begin{array}{l}\text { United } \\
\text { Kingdom }\end{array}$ & $\mathrm{N}=28$ & $\begin{array}{l}\text { Purposive } \\
\text { sampling } \\
\text { with } \\
\text { maximum } \\
\text { variation }\end{array}$ & $\begin{array}{l}\text { Not } \\
\text { reported }\end{array}$ & $\begin{array}{l}1 \text { men } \\
\text { withdre } \\
\text { w } \\
\text { consent } \\
\text { at } \\
\text { transcri } \\
\text { pt } \\
\text { checkin } \\
\text { g stage }\end{array}$ & $\begin{array}{l}\text { Cross-sectional } \\
\text { qualitative } \\
\text { study }\end{array}$ & $\begin{array}{l}1 \text { (median 3, } \\
0-15 \text { years } \\
\text { post } \\
\text { treatment) }\end{array}$ & $\begin{array}{l}\text { n28 } \\
\text { qualitative } \\
\text { interviews } \\
\text { ( } 37 \text { min-2 h } \\
17 \text { min, } \\
\text { average } \\
\text { interview was } \\
66 \text { min) }\end{array}$ \\
\hline
\end{tabular}


Table 4. Quality appraisal of primary studies

\begin{tabular}{|c|c|c|c|c|c|c|c|c|c|c|c|c|c|c|c|}
\hline \multirow[t]{2}{*}{ Qualitative Study } & \multicolumn{15}{|c|}{ Item number of check list } \\
\hline & 1 & 2 & 3 & 4 & 5 & 6 & 7 & 8 & 9 & 10 & 11 & 12 & 13 & 14 & 15 \\
\hline Bullen et al., 2010 & 2 & 2 & 2 & 2 & 2 & 1 & 2 & 2 & 1 & 2 & 2 & 2 & 2 & 1 & 2 \\
\hline Gordan et al., 2017 & 2 & 2 & 2 & 2 & 2 & 2 & 1 & 2 & 2 & 1 & 2 & 2 & 2 & 1 & 2 \\
\hline Mortensen \& Jakobsen 2013 & 2 & 1 & 1 & 1 & 0 & 1 & 0 & 0 & 2 & 0 & 0 & 0 & 1 & 0 & 1 \\
\hline Opjordsmoen et al., 1994 & 2 & 1 & 1 & 1 & 1 & 1 & 1 & 0 & $\overline{1}$ & 0 & 0 & 0 & 0 & 0 & 0 \\
\hline Skeppner et al., 2015 & 2 & 1 & 1 & 1 & 1 & 1 & 0 & 1 & 2 & 0 & o & 0 & 0 & 0 & 1 \\
\hline Skeppner et al., 2008 & 2 & 1 & 1 & 1 & 1 & 1 & 0 & 0 & 1 & 0 & 0 & 0 & 0 & 0 & 0 \\
\hline Witty et al., 2013 & 2 & 2 & 2 & 1 & 2 & 1 & 1 & 2 & 2 & 2 & 2 & 2 & 2 & 0 & 2 \\
\hline
\end{tabular}

Item number check list key*: 1 research question clearly described, 2 qualitative method appropriate, 3 setting/context clearly described, 4 sampling strategy dearly described, 5 sampling method likely to recruit all relevant cases, 6 characteristics of the sample provided, 7 rationale of sample sise given, 8 methods of data collection dearly described, 9 method of data collection appropriate for research question and paradizm, 10 has researcher verified data le.e. by triangulationl, 11 data analysis methods clearly described, 12 data analysis methods approgriate, 13 competing accounts/deviant data taken into account, 14 to what extend is the researcher reflective, 15 intergretations and conclusions supported by the data.

\begin{tabular}{|c|c|c|c|c|c|c|c|c|c|c|c|c|c|c|c|c|c|}
\hline \multirow[t]{2}{*}{ Quantitative Studies } & \multicolumn{17}{|c|}{ Item number of check list } \\
\hline & 1 & 2 & 3 & 4 & 5 & 6 & 7 & 8 & 9 & 10 & 11 & 12 & 13 & 14 & 15 & 16 & 17 \\
\hline Arturo et al., 1997 & 2 & 2 & 2 & 1 & MA & NA & NA & NA & 2 & $\mathrm{MA}$ & 1 & 1 & 1 & 1 & MM & $\mathrm{Ma}$ & 2 \\
\hline Bhat et al., 2018 & 2 & 1 & 1 & 1 & $\mathrm{MA}$ & Na & NA & MA & 2 & $\mathrm{KA}$ & 1 & 2 & 1 & 0 & NA & NA & 1 \\
\hline Drager et al., 2017 & 2 & 2 & ${ }^{\circ}$ & 1 & $\mathrm{Ma}$ & Na & Na & NA & 2 & $\mathrm{kA}$ & 1 & 2 & 2 & 1 & NM & MA & 2 \\
\hline Dulaunay et al., 2014 & 2 & 1 & 0 & 1 & Ka & NA & NA & NA & 2 & KA & 1 & 1 & 1 & 0 & NaA & NA & 2 \\
\hline Ficarra et $1 ., 2000$ & 2 & 2 & 2 & 2 & $\mathrm{MA}$ & Nas & NA & NA & 2 & 1 & 1 & 2 & 2 & 0 & Na & NA & 1 \\
\hline Kieffer et al., 2014 & 2 & 2 & 1 & 2 & $\mathrm{~N} / \mathrm{A}$ & N/A & $N / \mathrm{A}$ & $N / A$ & 2 & $\mathrm{~N} / \mathrm{h}$ & 1 & 2 & 2 & 2 & $\mathrm{~N} / \mathrm{A}$ & $N / A$ & 1 \\
\hline Soh et al., 2014 & 2 & 1 & 1 & 1 & N/A & N/A & N/A & N/A & 2 & N/A & 1 & 2 & 2 & 1 & ma & $\mathrm{N} / \mathrm{A}$ & 2 \\
\hline Sosnowskie et al., 2016 & 1 & 2 & 1 & 1 & N// & N/A & N/A & $N / A$ & 2 & $\mathrm{~N} / \mathrm{h}$ & 1 & 1 & 2 & 0 & $\mathrm{~N} / \mathrm{A}$ & $N / \AA$ & 1 \\
\hline Wan et al., 2018 & 2 & 1 & 2 & 1 & $\mathrm{~N} / \mathrm{A}$ & N/A & 1 & N/A & 2 & $\mathrm{~N} / \mathrm{A}$ & 2 & 2 & 2 & 2 & 0 & $N / A$ & 2 \\
\hline Windahl et al., 2004 & 1 & 1 & 1 & 1 & N/A & N/A & $N / A$ & $N / A$ & 1 & $N / / 4$ & 1 & 1 & 0 & 0 & N/A & $N / \mathrm{A}$ & 1 \\
\hline
\end{tabular}

item number check list key*; 1 is the hypothesik/aim/objective clearly described, 2 is the study design well described and appropriate, 3 method of patient/control group selection clearly described, 4 characteristics of the patient/control group clearly described, 5 were patients randomised to the intervention group, 6 was randomisation/aliocation concealed, 7 characteristic of patients lost to follow-up clearly described, 8 intervention dearly described, 9 main outcome measures clearly described, 10 was an attempted made to blind those measuring the primary outcome of the intervention, 11 population characteristics adequately described and controlled, 12 main findings clearly described, 13 methods of analysis appropriately and dearly described, 14 estimates of variance reported for main results, 15 analyses acjusted for different leneths of follow-wp, 16 data analysed accordine to intertien to treat principle, 17 conclusions supported by the results

-Three levels of assessment quality scores

Low risk of biss (2)

Undear risk of blas (1) 
Table 5. Frequency of unmet needs by domain.

\begin{tabular}{|c|c|c|c|c|c|c|c|c|c|c|c|c|}
\hline Study & $\begin{array}{l}\text { Cognitive } \\
\text { Need }\end{array}$ & $\begin{array}{l}\text { Physical } \\
\text { Needs }\end{array}$ & $\begin{array}{l}\text { Psychological/ } \\
\text { Emotional } \\
\text { Needs }\end{array}$ & $\begin{array}{l}\text { Family } \\
\text { Related } \\
\text { Needs }\end{array}$ & $\begin{array}{l}\text { Social } \\
\text { Needs }\end{array}$ & \begin{tabular}{|l} 
Interpersonal// \\
Intimacy \\
Needs
\end{tabular} & $\begin{array}{l}\text { Practical } \\
\text { Needs }\end{array}$ & $\begin{array}{l}\text { Daily Living } \\
\text { Needs }\end{array}$ & \begin{tabular}{|l} 
Spiritual \\
Needs
\end{tabular} & $\begin{array}{l}\text { Health System/ } \\
\text { Information } \\
\text { Needs }\end{array}$ & $\begin{array}{l}\text { Patient-Clinician } \\
\text { Communication }\end{array}$ & $\begin{array}{l}\text { Number of domains } \\
\text { explored within each } \\
\text { study }\end{array}$ \\
\hline $\begin{array}{l}\text { Arturo et } \\
\text { al., } 1997 \\
\text { (Brazil) }\end{array}$ & - & $\checkmark$ & $\checkmark$ & - & $\checkmark$ & - & - & - & - & - & - & 3 \\
\hline $\begin{array}{l}\text { Bhat et al. } \\
\text { (2018) } \\
\text { (India) }\end{array}$ & - & - & $\checkmark$ & - & - & $\checkmark \checkmark$ & - & - & $\checkmark \checkmark$ & - & - & 3 \\
\hline $\begin{array}{l}\text { Bullen et } \\
\text { al. (2009), } \\
2010 \text { (UK) }\end{array}$ & - & $\checkmark$ & $\checkmark$ & $\checkmark$ & $\checkmark$ & $\checkmark$ & $\checkmark$ & $\checkmark$ & $\checkmark$ & $\checkmark$ & $\checkmark$ & 10 \\
\hline $\begin{array}{l}\text { Drager et } \\
\text { al. (2017) } \\
\text { (Germany) }\end{array}$ & - & $\checkmark$ & $\checkmark$ & - & - & $\checkmark$ & - & - & - & $\checkmark$ & - & 4 \\
\hline $\begin{array}{l}\text { Delaunay } \\
\text { et al., } \\
2014 \\
\text { (Spain/Fra } \\
\text { nce) }\end{array}$ & - & $\checkmark$ & - & - & - & $\checkmark$ & - & - & - & $\checkmark$ & - & 3 \\
\hline $\begin{array}{l}\text { Ficarra et } \\
\text { al. (2000) } \\
\text { (Italy) }\end{array}$ & - & $\checkmark$ & $\checkmark$ & - & - & $\checkmark$ & - & - & - & - & - & 3 \\
\hline $\begin{array}{l}\text { Gordon et } \\
\text { al., } 2017 \\
\text { (USA) }\end{array}$ & - & $\checkmark$ & $\checkmark$ & $\checkmark$ & $\checkmark$ & $\checkmark$ & - & - & $\checkmark$ & $\checkmark$ & $\checkmark$ & 8 \\
\hline $\begin{array}{l}\text { Kieffer et } \\
\text { al. (2014) } \\
\text { (Denmark) }\end{array}$ & - & $\checkmark$ & $\checkmark$ & - & - & $\checkmark$ & - & $\checkmark$ & - & - & - & 4 \\
\hline
\end{tabular}




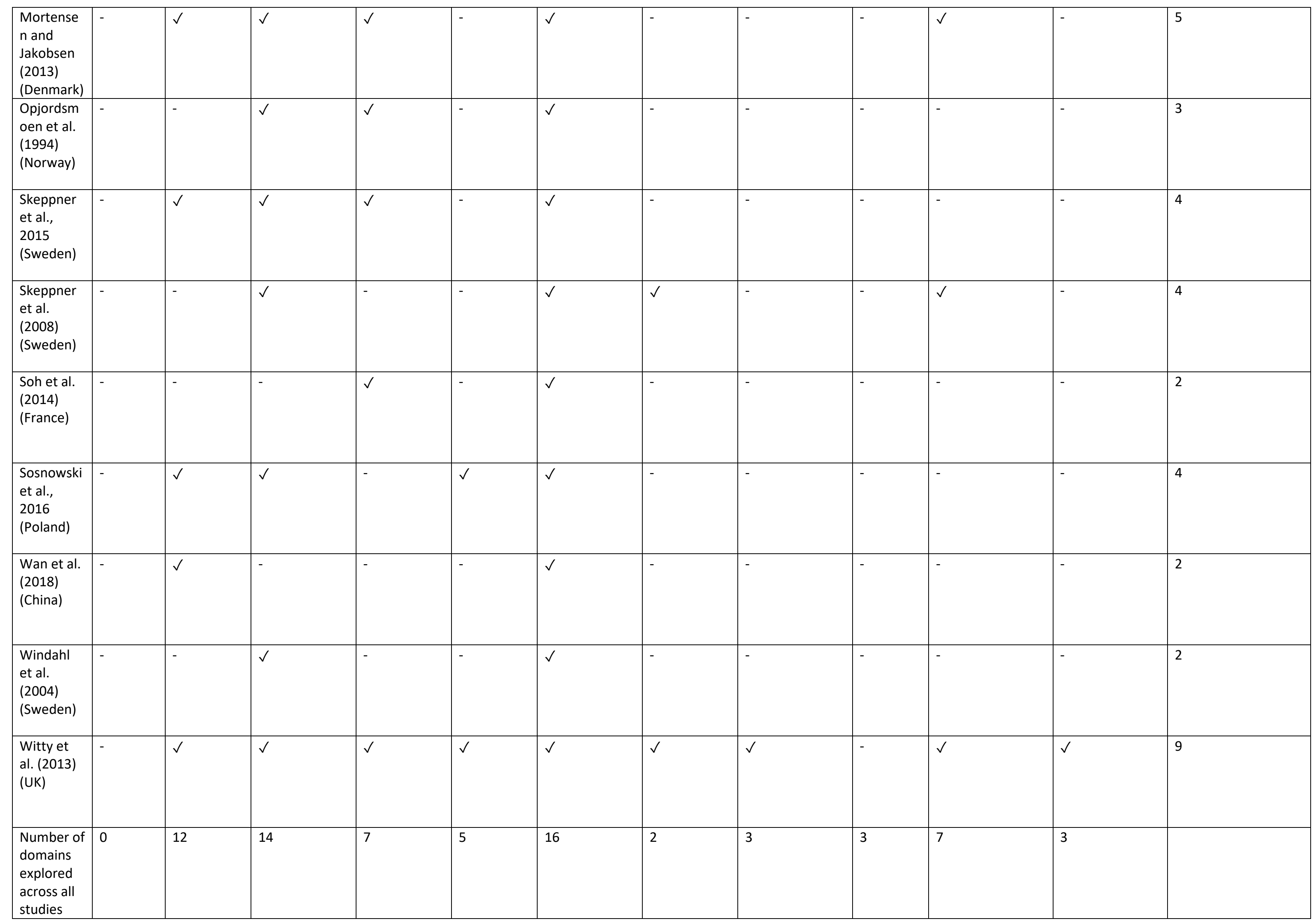




\begin{tabular}{|c|c|c|c|c|c|c|c|c|c|c|c|}
\hline $\begin{array}{l}\text { Author and } \\
\text { Year }\end{array}$ & Physical Needs & $\begin{array}{l}\text { Psychological/Emotion } \\
\text { al Needs }\end{array}$ & \begin{tabular}{|l} 
Cognitiv \\
e Needs
\end{tabular} & \begin{tabular}{|l|} 
Patient- \\
Clinician \\
Information \\
Needs \\
\end{tabular} & $\begin{array}{l}\text { Health } \\
\text { System/Informatio } \\
\mathrm{n} \text { Needs }\end{array}$ & $\begin{array}{l}\text { Spiritual } \\
\text { Needs/Existenti } \\
\text { al }\end{array}$ & \begin{tabular}{|l} 
Daily Living \\
Needs
\end{tabular} & $\begin{array}{l}\text { Interpersonal/intimac } \\
\text { y Needs }\end{array}$ & \begin{tabular}{|l} 
Practical \\
Needs
\end{tabular} & \begin{tabular}{|l} 
Family Related \\
Needs
\end{tabular} & \begin{tabular}{|l} 
Social Needs \\
\end{tabular} \\
\hline $\begin{array}{l}\text { Bhat et al. } \\
\text { (2018) }\end{array}$ & Not reported. & $\begin{array}{l}\text { Sexual interest was less } \\
\text { in partners of patients } \\
\text { with the partial } \\
\text { penectomy. Masculine } \\
\text { image was intact with } \\
\text { those with partial and } \\
\text { lost in those with total } \\
\text { penectomy } \\
\end{array}$ & \begin{tabular}{|l|} 
Not \\
reported \\
.
\end{tabular} & Not reported. & Not reported. & Not reported. & Not reported. & $\begin{array}{l}\text { In all patients the } \\
\text { relationship with their } \\
\text { partners was affected } \\
\text { by sexual } \\
\text { dissatisfaction. } 90 \% \\
\text { of the patients had } \\
\text { anxiety about their } \\
\text { performance. }\end{array}$ & \begin{tabular}{|l} 
Not \\
reported.
\end{tabular} & Not reported. & Not reported. \\
\hline $\begin{array}{l}\text { Bullen et al. } \\
\text { (2009): } \\
\text { reporting } \\
\text { same results } \\
\text { as }\end{array}$ & $\begin{array}{l}\text { Reduced physical } \\
\text { strength and inability to } \\
\text { work and participate in } \\
\text { exercise. The physical } \\
\text { consequences of surgery } \\
\text { for sexual and urinary } \\
\text { function was life } \\
\text { changing. Difficulties } \\
\text { with sleeping. }\end{array}$ & $\begin{array}{l}\text { Men noted change in } \\
\text { sense of masculinity. } \\
\text { Profound psychological } \\
\text { impact of a cancer } \\
\text { diagnosis and } \\
\text { implications of having } \\
\text { surgery. When seeking } \\
\text { support men were } \\
\text { faced with the } \\
\text { dilemma for keeping } \\
\text { the diagnosis a secret } \\
\text { due to embarrassment } \\
\text { and stigma. }\end{array}$ & \begin{tabular}{|l|} 
Not \\
reported \\
\end{tabular} & $\begin{array}{l}\text { Limitations } \\
\text { noted in } \\
\text { rehabilitation } \\
\text { and patients } \\
\text { express that } \\
\text { this was a } \\
\text { trial and } \\
\text { error } \\
\text { process. Lack } \\
\text { of advice on } \\
\text { how to cope } \\
\text { with the } \\
\text { sexuality and } \\
\text { urination. }\end{array}$ & $\begin{array}{l}\text { Lack of awareness } \\
\text { of the implications } \\
\text { of surgery and lack } \\
\text { of counselling } \\
\text { about the inability } \\
\text { to have } \\
\text { penetrative sex. } \\
\text { Missed and } \\
\text { incorrect diagnosis }\end{array}$ & $\begin{array}{l}\text { Existential } \\
\text { threat and } \\
\text { concerns of } \\
\text { feelings of shock } \\
\text { and disbelief } \\
\text { accompanied } \\
\text { with feelings of } \\
\text { fear and } \\
\text { disappear. }\end{array}$ & $\begin{array}{l}\text { Men required to } \\
\text { sit down to } \\
\text { urinate due to } \\
\text { inability to } \\
\text { control urine } \\
\text { flow. This leads } \\
\text { to concerns } \\
\text { about restroom } \\
\text { use (cleanliness, } \\
\text { embarrassment) } \\
\text {. Patients } \\
\text { reported } \\
\text { inability to } \\
\text { return to work, } \\
\text { maintain their } \\
\text { status as } \\
\text { "breadwinner" }\end{array}$ & $\begin{array}{l}\text { Married men } \\
\text { expressed long term } \\
\text { concerns about } \\
\text { satisfying partner, } \\
\text { unmarried men } \\
\text { avoided new } \\
\text { relationships out of } \\
\text { fear of ridicule and } \\
\text { rejection. Majority of } \\
\text { men reported } \\
\text { friendships and } \\
\text { relationships were } \\
\text { damaged or lost. One } \\
\text { wife was noted to cry } \\
\text { and state "what have } \\
\text { they done" when } \\
\text { viewing the surgical } \\
\text { results for the first } \\
\text { time. Men and } \\
\text { partners report } \\
\text { frustration because of } \\
\text { inability to achieve } \\
\text { orgasm and the } \\
\text { inability to do } \\
\text { anything about it. }\end{array}$ & \begin{tabular}{|l|} 
Men \\
expressed \\
difficulty \\
with \\
walking.
\end{tabular} & $\begin{array}{l}\text { Implications of } \\
\text { having } \\
\text { children. } \\
\text { Challenges of } \\
\text { maintaining } \\
\text { roles as } \\
\text { husband, lover } \\
\text { and father. }\end{array}$ & $\begin{array}{l}\text { Some men } \\
\text { expressed they } \\
\text { no longer } \\
\text { participate in } \\
\text { sports or drinking } \\
\text { activities with } \\
\text { social groups. } \\
\text { Need to avoid } \\
\text { communal } \\
\text { showers/changin } \\
\mathrm{g} \text { rooms. }\end{array}$ \\
\hline $\begin{array}{l}\text { D'Ancona et } \\
\text { al., } 1997\end{array}$ & $\begin{array}{l}\text { Discomfort of having to } \\
\text { sit down during } \\
\text { urination. }\end{array}$ & $\begin{array}{l}\text { The impact of diagnosis } \\
\text { and treatment resulted } \\
\text { fears of mutilation and } \\
\text { a lack of sexual } \\
\text { pleasure. Fear of dying } \\
\text { and the consequences } \\
\text { for the family. } \\
\text { Significant anxiety of } \\
\text { depression was } \\
\text { reported (HADS). }\end{array}$ & \begin{tabular}{|l|} 
Not \\
reported \\
\end{tabular} & Not reported. & Not reported. & Not reported. & Not reported. & Not reported. & $\begin{array}{l}\text { Not } \\
\text { reported. }\end{array}$ & Not reported. & $\begin{array}{l}2 \text { patients out of } \\
14 \text { reported } \\
\text { being a little } \\
\text { unsatisfied with } \\
\text { their job as well } \\
\text { as having } \\
\text { financial } \\
\text { difficulties, both } \\
\text { of which became } \\
\text { worse after } \\
\text { surgery. }\end{array}$ \\
\hline
\end{tabular}




\begin{tabular}{|c|c|c|c|c|c|c|c|c|c|c|c|}
\hline $\begin{array}{l}\text { Drager et al. } \\
\text { (2017) }\end{array}$ & $\begin{array}{l}\text { Difficulties with } \\
\text { urination, limitations in } \\
\text { mobility and pain and } \\
\text { exhaustion. }\end{array}$ & $\begin{array}{l}2.5 \% \text { of the men } \\
\text { reported a need for } \\
\text { psychosocial help. } \\
\text { Patients reported } \\
\text { sorrow, anxiety and } \\
\text { sadness. }\end{array}$ & \begin{tabular}{|l|} 
Not \\
reported \\
\end{tabular} & Not reported. & $\begin{array}{l}\text { Patients reported } \\
\text { increased } \\
\text { psychological } \\
\text { distress and need } \\
\text { for psychosocial } \\
\text { care }\end{array}$ & Not reported. & Not reported. & $\begin{array}{l}\text { 16\% reported sexual } \\
\text { dysfunction needs. }\end{array}$ & \begin{tabular}{|l|}
$\begin{array}{l}\text { Not } \\
\text { reported. }\end{array}$ \\
\end{tabular} & Not reported. & Not reported. \\
\hline $\begin{array}{l}\text { Dulaunay et } \\
\text { al. (2014) }\end{array}$ & $\begin{array}{l}\text { Needs related to } \\
\text { changes in sensations of } \\
\text { the gland, } \\
\text { discomfort/pain, altered } \\
\text { appearance, frequent } \\
\text { bleeding and rate of } \\
\text { meatal stenosis was } \\
21.1 \% .\end{array}$ & Not reported. & \begin{tabular}{|l|} 
Not \\
reported \\
\end{tabular} & Not reported. & $\begin{array}{l}\text { Men report being } \\
\text { "poorly informed" } \\
\text { regarding } \\
\text { consequences of } \\
\text { penile } \\
\text { brachytherapy on } \\
\text { sexuality and a } \\
\text { general lack of } \\
\text { information. }\end{array}$ & Not reported. & Not reported. & $\begin{array}{l}\text { Some men reported } \\
\text { being unsatisfied with } \\
\text { sexual life. }\end{array}$ & \begin{tabular}{|l|} 
Not \\
reported.
\end{tabular} & Not reported. & Not reported. \\
\hline $\begin{array}{l}\text { Ficarra et al. } \\
(2000)\end{array}$ & $\begin{array}{l}\text { General state of health } \\
\text { was impaired in } 37.5 \% \text { of } \\
\text { patients undergoing } \\
\text { partial penectomy which } \\
\text { was statistically } \\
\text { significant ( } p=0.008 \text { ) } \\
\text { compared to controls } \\
\text { (non-malignant BHP } \\
\text { surgical patients). }\end{array}$ & \begin{tabular}{|l|} 
Depression was \\
observed in $6.8 \%$ of \\
patients undergoing \\
partial penectomy. \\
Pathological levels of \\
anxiety was reported in \\
$31 \%$ of patients \\
undergoing partial \\
penectomy.
\end{tabular} & \begin{tabular}{|l|} 
Not \\
reported \\
\end{tabular} & Not reported. & Not reported. & Not reported. & Not reported. & $\begin{array}{l}\text { Altered function and } \\
\text { ability in sexual } \\
\text { activity and } \\
\text { performance. }\end{array}$ & \begin{tabular}{|l|l} 
Not \\
reported.
\end{tabular} & Not reported. & Not reported. \\
\hline $\begin{array}{l}\text { Gordon et } \\
\text { al., } 2017\end{array}$ & $\begin{array}{l}\text { Urination and side } \\
\text { effects which included: } \\
\text { lack of control urination, } \\
\text { swelling, itching; and } \\
\text { erectile dysfunction. }\end{array}$ & $\begin{array}{l}\text { Concerns related to the } \\
\text { ability to disclose } \\
\text { diagnosis to family and } \\
\text { friends. Barriers related } \\
\text { to fear of } \\
\text { stigmatisation and } \\
\text { embarrassment; } \\
\text { psychological distress } \\
\text { in coping with the } \\
\text { emotional turmoil } \\
\text { including shock-anxiety } \\
\text {-anger-fear-denial. } \\
\text { Men expressed being } \\
\text { very scared and } \\
\text { multiple episodes of } \\
\text { feeling suicidal. }\end{array}$ & \begin{tabular}{|l} 
Not \\
reported \\
\end{tabular} & $\begin{array}{l}\text { A lack of } \\
\text { trust and } \\
\text { dissatisfactio } \\
\mathrm{n} \text { with } \\
\text { trajectory of } \\
\text { diagnosis to } \\
\text { treatment. } \\
\text { Lack of } \\
\text { professional } \\
\text { help with } \\
\text { changes in } \\
\text { sexual life } \\
\text { and physical } \\
\text { function. } \\
\text { Lack of } \\
\text { compassion. }\end{array}$ & \begin{tabular}{|l|} 
Lack of doctor's \\
knowledge and \\
ability to provide \\
timely and \\
accurate diagnosis. \\
No access to \\
supportive care.
\end{tabular} & $\begin{array}{l}\text { Challenges to } \\
\text { manhood, } \\
\text { acceptance and } \\
\text { multiple } \\
\text { accounts of } \\
\text { suicidal ideation. } \\
\text { Several men } \\
\text { have lost faith at } \\
\text { some point } \\
\text { during the } \\
\text { sickness } \\
\text { trajectory. }\end{array}$ & Not reported. & $\begin{array}{l}\text { Several men } \\
\text { expressed that penile } \\
\text { cancer resulted in } \\
\text { marital problems. } \\
\text { Lack of support from } \\
\text { partners, wives not } \\
\text { visiting in hospital } \\
\text { after surgery. Men } \\
\text { felt that treatment } \\
\text { ruined their sex life. } \\
\text { They were being } \\
\text { deprived of } \\
\text { something genuine } \\
\text { and very natural, sex } \\
\text { life. }\end{array}$ & \begin{tabular}{|l|l} 
Not \\
reported.
\end{tabular} & $\begin{array}{l}\text { The spouses } \\
\text { that } \\
\text { accompanied } \\
\text { the patients in } \\
\text { the interviews } \\
\text { expressed } \\
\text { their own } \\
\text { needs and } \\
\text { impact of } \\
\text { penile cancer. }\end{array}$ & $\begin{array}{l}\text { Fear of creating a } \\
\text { mess when using } \\
\text { other people's } \\
\text { toilet. }\end{array}$ \\
\hline $\begin{array}{l}\text { Kieffer et al. } \\
\text { (2014) }\end{array}$ & $\begin{array}{l}\text { The most frequently } \\
\text { reported reasons for } \\
\text { leakage included } \\
\text { spraying urine flow } n \\
\text { (NR) (35\%) and that the } \\
\text { penile was too short } n \\
\text { (NR) (35\%). } \\
\text { Approximately, a quarter } \\
\text { of the men reported } \\
\text { having to sit while }\end{array}$ & $\begin{array}{l}\text { Men who underwent } \\
\text { partial penectomy } \\
\text { reported significantly } \\
\text { more appearance } \\
\text { concerns than men } \\
\text { treated by penile } \\
\text { sparing surgery } \\
p=.008) \text {. Patients } \\
\text { reported worry. }\end{array}$ & \begin{tabular}{|l} 
Not \\
reported \\
.
\end{tabular} & Not reported. & Not reported. & Not reported. & \begin{tabular}{|l} 
Patients treated \\
by partial \\
penectomy \\
reported more \\
concerns with \\
life \\
interferences \\
than men \\
treated with \\
penile sparing \\
surgery
\end{tabular} & $\begin{array}{l}\text { No significant } \\
\text { differences observed } \\
\text { for erectile function, } \\
\text { sexual desire, } \\
\text { intercourse } \\
\text { satisfaction or over } \\
\text { satisfaction between } \\
\text { both treatment } \\
\text { groups } P>.05 \text {. A } \\
\text { significant difference } \\
\text { was observed in }\end{array}$ & \begin{tabular}{|l|}
$\begin{array}{l}\text { Not } \\
\text { reported. }\end{array}$
\end{tabular} & Not reported. & Not reported. \\
\hline
\end{tabular}




\begin{tabular}{|c|c|c|c|c|c|c|c|c|c|c|c|}
\hline & $\begin{array}{l}\text { urinating because of the } \\
\text { perineal urethrostomy. }\end{array}$ & & & & & & $\begin{array}{l}p=.032 \text {. Details } \\
\text { of the specific } \\
\text { areas of life } \\
\text { interferences } \\
\text { were not } \\
\text { reported. }\end{array}$ & $\begin{array}{l}\text { orgasmic function in } \\
\text { favour of the penile } \\
\text { sparing patient group } \\
p=.033 \text {. }\end{array}$ & & & \\
\hline $\begin{array}{l}\text { Mortensen } \\
\text { \& Jakobsen } \\
\text { (2013) }\end{array}$ & $\begin{array}{l}\text { Complications with } \\
\text { closed urinary tracts was } \\
\text { painful and men } \\
\text { reported of being upset } \\
\text { to perform self- } \\
\text { catheterisation. General } \\
\text { decline in physical } \\
\text { function. Challenges } \\
\text { with sitting down to } \\
\text { urinate. }\end{array}$ & $\begin{array}{l}\text { Loss of masculinity. } \\
\text { Some men develop } \\
\text { panic attacks } \\
\text { manifesting as stomach } \\
\text { aches and breathing } \\
\text { difficulties. } \\
\text { Unmanaged anxiety } \\
\text { issues. }\end{array}$ & $\begin{array}{l}\text { Not } \\
\text { reported }\end{array}$ & Not reported & $\begin{array}{l}\text { Most of the } \\
\text { participants } \\
\text { delayed seeking } \\
\text { medical attention } \\
\text { by } 1.5-2 \text { years due } \\
\text { to feelings of } \\
\text { embarrassment. } \\
\text { None of the } \\
\text { participants were } \\
\text { offered any form } \\
\text { of rehabilitation. }\end{array}$ & Fear of dying. & Not reported & $\begin{array}{l}\text { None of the mature } \\
\text { relationship } \\
\text { experience an impact } \\
\text { on the sex life that } \\
\text { was of adversely } \\
\text { affected on the } \\
\text { relationship due to } \\
\text { being older. Younger } \\
\text { single men reported } \\
\text { profound problems } \\
\text { with trying to meet } \\
\text { partners due to } \\
\text { embarrassment and } \\
\text { perceived sharing the } \\
\text { diagnosis would scare } \\
\text { or repulse women. }\end{array}$ & $\begin{array}{l}\text { Not } \\
\text { reported }\end{array}$ & $\begin{array}{l}\text { Implications } \\
\text { for having a } \\
\text { family for } \\
\text { younger men } \\
\text { reported as an } \\
\text { issue. }\end{array}$ & Not reported \\
\hline $\begin{array}{l}\text { Opjordsmoe } \\
\mathrm{n} \text { et al. } \\
\text { (1994) }\end{array}$ & Not reported. & $\begin{array}{l}\text { Men experienced social } \\
\text { phobia and post- } \\
\text { traumatic stress } \\
\text { disorder, alcohol } \\
\text { abuse. Major } \\
\text { depression was } \\
\text { associated with } \\
\text { complete non-sexual } \\
\text { function. }\end{array}$ & $\begin{array}{l}\text { Not } \\
\text { reported }\end{array}$ & Not reported. & Not reported & Not reported & Not reported & $\begin{array}{l}\text { Problems with } \\
\text { erection, changes in } \\
\text { ability to having sex. } \\
\text { Changes in } \\
\text { relationships and } \\
\text { distressed partner } \\
\text { relationships. }\end{array}$ & $\begin{array}{l}\text { Not } \\
\text { reported }\end{array}$ & $\begin{array}{l}\text { Men reported } \\
\text { problems with } \\
\text { marriage and } \\
\text { martial crisis } \\
\text { after } \\
\text { treatment. } \\
\text { Some men } \\
\text { subsequently } \\
\text { divorced due } \\
\text { to problems } \\
\text { after therapy. }\end{array}$ & Not reported \\
\hline $\begin{array}{l}\text { Skeppner et } \\
\text { al., } 2015\end{array}$ & $\begin{array}{l}\text { Half of the men reported } \\
\text { genital sexual pain, } \\
\text { decreased sensitivity of } \\
\text { the penis, retarded } \\
\text { ejaculation/anejaculatio } \\
\mathrm{n} \text {. }\end{array}$ & $\begin{array}{l}\text { Anxiety was present in } \\
\text { partners at baseline } \\
\text { and } 12 \text { months follow- } \\
\text { up. Difficulties in } \\
\text { shared coping } \\
\text { processes and } \\
\text { strategies. }\end{array}$ & $\begin{array}{l}\text { Not } \\
\text { reported }\end{array}$ & Not reported. & Not reported & Not reported & Not reported & $\begin{array}{l}\text { Couples reported } \\
\text { withdrawal in sexual } \\
\text { activity due to penile } \\
\text { cancer and its } \\
\text { treatment. All couples } \\
\text { reported low sexual } \\
\text { satisfaction. }\end{array}$ & $\begin{array}{l}\text { Not } \\
\text { reported }\end{array}$ & $\begin{array}{l}\text { Cancer } \\
\text { affected the } \\
\text { dyadic } \\
\text { processes of } \\
\text { the couple's } \\
\text { adjustment } \\
\text { and reduced } \\
\text { communicatio } \\
\mathrm{n} \text { together. }\end{array}$ & Not reported. \\
\hline $\begin{array}{l}\text { Skeppner et } \\
\text { al.,. (2008) }\end{array}$ & Not reported. & $\begin{array}{l}\text { Reduced psychological } \\
\text { well-being. }\end{array}$ & $\begin{array}{l}\text { Not } \\
\text { reported }\end{array}$ & Not reported. & $\begin{array}{l}\text { Delay in seeking } \\
\text { medical attention } \\
\text { from initial } \\
\text { symptoms more } \\
\text { than } 6 \text { months. }\end{array}$ & Not reported. & Not reported & $\begin{array}{l}\text { Dissatisfaction with } \\
\text { sexual life. }\end{array}$ & $\begin{array}{l}\text { Reduced } \\
\text { satisfaction } \\
\text { with } \\
\text { economic } \\
\text { provision. } \\
\text { Further } \\
\text { explanatio } \\
\mathrm{n} \text { not } \\
\text { provided. }\end{array}$ & Not reported. & Not reported. \\
\hline
\end{tabular}




\begin{tabular}{|c|c|c|c|c|c|c|c|c|c|c|c|}
\hline $\begin{array}{l}\text { Soh et al. } \\
\text { (2014) }\end{array}$ & Not reported. & Not reported. & \begin{tabular}{|l} 
Not \\
reported \\
\end{tabular} & Not reported. & Not reported. & Not reported. & Not reported. & \begin{tabular}{|l} 
No patients reported \\
that they felt a loss of \\
manliness or were \\
worried about sexual \\
performance. (n2) \\
Patients reported a \\
loss of sexual desire, \\
(n7) reported a low or \\
very low desire.
\end{tabular} & \begin{tabular}{|l|} 
Not \\
reported
\end{tabular} & \begin{tabular}{|l} 
(n14) declared \\
their partners \\
"understood \\
and accepted" \\
their sexual \\
dysfunction; \\
(n1) wife was \\
"disappointed \\
with sexual \\
dysfunction", \\
(n3) she "did \\
not express \\
any opinion \\
concerning \\
sexuality and \\
(n1) wife \\
expressed \\
"wishes I \\
recovered my \\
sexual \\
performance".
\end{tabular} & Not reported \\
\hline $\begin{array}{l}\text { Sosnowski et } \\
\text { al., } 2016\end{array}$ & $\begin{array}{l}\text { Physical function median } \\
\text { was reduced at } 70 \\
\text { (EORTC) }\end{array}$ & \begin{tabular}{|l} 
Patients reported \\
reduced self-esteem \\
median $75 \%$, ranged \\
$67 \%-87 \%$. Patients \\
reported reduced \\
emotional functioning.
\end{tabular} & \begin{tabular}{|l|} 
Not \\
reported \\
\end{tabular} & Not reported. & Not reported. & Not reported. & Not reported. & $\begin{array}{l}\text { Majority of the } \\
\text { patients did not } \\
\text { experience orgasm } \\
\text { and ejaculation } \\
\text { during sexual activity. } \\
\text { Sexual relations with } \\
\text { a partner were } \\
\text { defined as very } \\
\text { unsatisfactory, } \\
\text { however, one patient } \\
\text { described relations as } \\
\text { very "rewarding". }\end{array}$ & \begin{tabular}{|l|} 
Not \\
reported.
\end{tabular} & Not reported. & $\begin{array}{l}\text { Patients reported } \\
\text { reduced social } \\
\text { functioning.. }\end{array}$ \\
\hline $\begin{array}{l}\text { Wan et al. } \\
\text { (2018) }\end{array}$ & $\begin{array}{l}\mathrm{n} 15 \text { all reported being } \\
\text { able to micturate while } \\
\text { standing, no cystitis or } \\
\text { incontinence. } \mathrm{n} 1 \mathrm{man} \\
\text { reported spraying of } \\
\text { urine while micturating. }\end{array}$ & Not reported. & \begin{tabular}{|l} 
Not \\
reported \\
.
\end{tabular} & Not reported. & Not reported. & Not reported. & Not reported. & $\begin{array}{l}\text { Patients reported } \\
\text { decrements in sexual } \\
\text { relationships and } \\
\text { confident levels prior } \\
\text { to surgery. However, } \\
\text { a statistically } \\
\text { significant } \\
\text { improvement in these } \\
\text { both domains were } \\
\text { reported at } 6 \text { months. } \\
\text { However, orgasmic } \\
\text { function decreased } \\
\text { after surgery. }\end{array}$ & $\begin{array}{l}\text { Not } \\
\text { reported. }\end{array}$ & Not reported. & Not reported. \\
\hline $\begin{array}{l}\text { Windahl et } \\
\text { al. (2004) }\end{array}$ & Not reported. & $\begin{array}{l}\text { Decreases in sexual } \\
\text { desire and interest } \\
\text { were related to } \\
\text { psychological needs. }\end{array}$ & $\begin{array}{l}\text { Not } \\
\text { reported } \\
\end{array}$ & Not reported. & Not reported. & Not reported. & Not reported. & $\begin{array}{l}\text { Patients reported } \\
\text { distress in sexual } \\
\text { interest (n7), distress } \\
\text { in quality of erections }\end{array}$ & \begin{tabular}{|l|} 
Not \\
reported.
\end{tabular} & Not reported. & Not reported. \\
\hline
\end{tabular}




\begin{tabular}{|c|c|c|c|c|c|c|c|c|c|c|c|}
\hline & & & & & & & & $\begin{array}{l}\text { (n2), distress in early } \\
\text { ejaculation ( } \mathrm{n} 1 \text { ) and } \\
\text { distress caused by } \\
\text { dyspareunia (n6). } \\
\text { Distress in these } \\
\text { domains were } \\
\text { persistent following } \\
\text { treatment. Painful } \\
\text { intercourse caused } \\
\text { distress. }\end{array}$ & & & \\
\hline \begin{tabular}{|l} 
Witty et al. \\
(2013)
\end{tabular} & $\begin{array}{l}\text { Difficulties with urinary } \\
\text { function, spraying and } \\
\text { inconsistent flow. One } \\
\text { man had an urostomy } \\
\text { which he considered to } \\
\text { be messy and } \\
\text { impractical. Post-surgical } \\
\text { men experienced } \\
\text { infection which inhibited } \\
\text { them from moving on } \\
\text { emotionally and } \\
\text { physically. Loss of } \\
\text { mobility and lethargic } \\
\text { after treatment. Other } \\
\text { health concerns included } \\
\text { lymphoedema because } \\
\text { of lymph node removal. }\end{array}$ & $\begin{array}{l}\text { The physical scaring } \\
\text { made men worried if } \\
\text { their cancer had } \\
\text { returned over time. } \\
\text { Men talked about } \\
\text { experiencing } \\
\text { depression after the } \\
\text { trauma of the } \\
\text { operation. Men talked } \\
\text { about feelings of loss, } \\
\text { low and anxious, and } \\
\text { having mood swings } \\
\text { which was damaging } \\
\text { relationships with } \\
\text { partners. Some men } \\
\text { reported feeling } \\
\text { "emasculated" and not } \\
\text { feeling like a "man" } \\
\text { due to a disconnect in } \\
\text { self-image. }\end{array}$ & \begin{tabular}{|l} 
Not \\
reported \\
\end{tabular} & $\begin{array}{l}\text { Some men } \\
\text { reported } \\
\text { being poorly } \\
\text { counselled } \\
\text { about the } \\
\text { extent of the } \\
\text { surgery and } \\
\text { completed } \\
\text { shocked } \\
\text { when he } \\
\text { seen the } \\
\text { results. }\end{array}$ & $\begin{array}{l}\text { Some men } \\
\text { reported that } \\
\text { counselling and } \\
\text { psychosexual } \\
\text { services were not } \\
\text { offered to them, } \\
\text { but they would } \\
\text { have found this } \\
\text { helpful. Some men } \\
\text { also reported a } \\
\text { lack of information } \\
\text { about what to } \\
\text { expect after } \\
\text { surgery. }\end{array}$ & Not reported. & $\begin{array}{l}\text { Men needed } \\
\text { public access to } \\
\text { disabled toilets } \\
\text { when away } \\
\text { from home, } \\
\text { which could be } \\
\text { problematic at } \\
\text { times. }\end{array}$ & $\begin{array}{l}\text { Men expressed that } \\
\text { their own lack of } \\
\text { sexual gratification } \\
\text { was less of a concern } \\
\text { than feelings of being } \\
\text { unable to satisfy their } \\
\text { partner. Men } \\
\text { expressed that they } \\
\text { were denying } \\
\text { wives/partners sexual } \\
\text { satisfaction for what } \\
\text { they deserved. Sexual } \\
\text { urges after total } \\
\text { penectomy } \\
\text { contributed to a } \\
\text { disconnection } \\
\text { between sensory self } \\
\text { and physical self. } \\
\text { Other men were able } \\
\text { to maintain a sex life, } \\
\text { but it was "different" } \\
\text { but still enjoyable. }\end{array}$ & $\begin{array}{l}\text { Men } \\
\text { reported } \\
\text { urination } \\
\text { was helped } \\
\text { by aids, } \\
\text { such as a } \\
\text { funell, } \\
\text { practicing } \\
\text { using the } \\
\text { toilet and } \\
\text { having to } \\
\text { re-train } \\
\text { themselves } \\
\text {. Men } \\
\text { found it } \\
\text { easier to } \\
\text { sit down. } \\
\text { Men } \\
\text { needed } \\
\text { access to a } \\
\text { cubical to } \\
\text { sit down. }\end{array}$ & $\begin{array}{l}\text { Support from } \\
\text { wives and } \\
\text { partners was } \\
\text { frequently } \\
\text { referenced as } \\
\text { an important } \\
\text { factor in } \\
\text { coping with } \\
\text { the impact of } \\
\text { surgery. Men } \\
\text { did not feel } \\
\text { able to share } \\
\text { their diagnosis } \\
\text { beyond their } \\
\text { immediate } \\
\text { family due to } \\
\text { embarrassmen } \\
\text { t and privacy } \\
\text { as reasons. }\end{array}$ & $\begin{array}{l}\text { Some men } \\
\text { reported about } \\
\text { experiencing low } \\
\text { confidence and } \\
\text { struggling to } \\
\text { interact with } \\
\text { others. It } \\
\text { inhibited social } \\
\text { activities which } \\
\text { involved wearing } \\
\text { shorts due to the } \\
\text { believe that } \\
\text { people would see } \\
\text { that patients } \\
\text { have had a } \\
\text { penectomy. }\end{array}$ \\
\hline
\end{tabular}




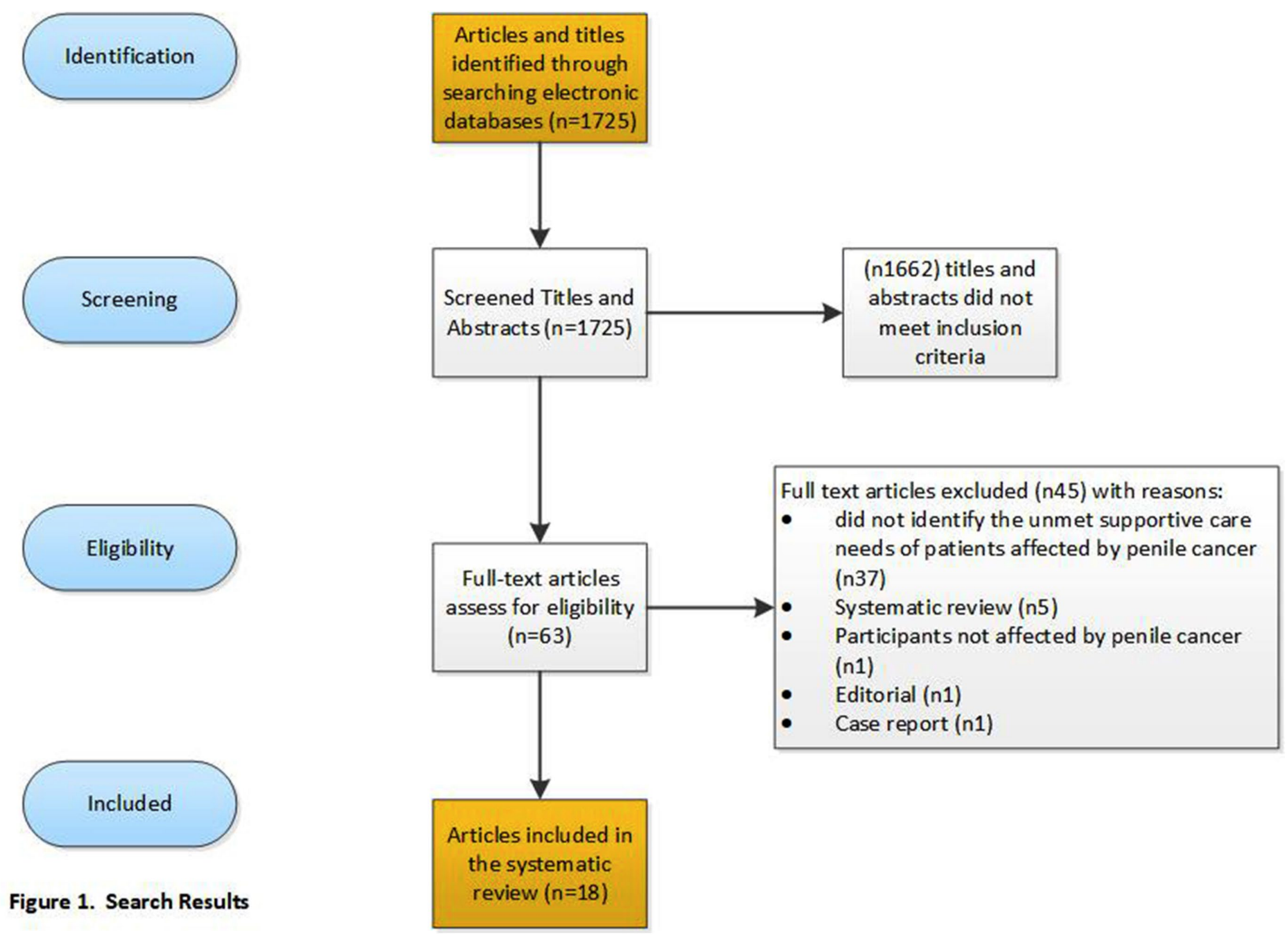


Supplementary File 1. Literature Search Strategy

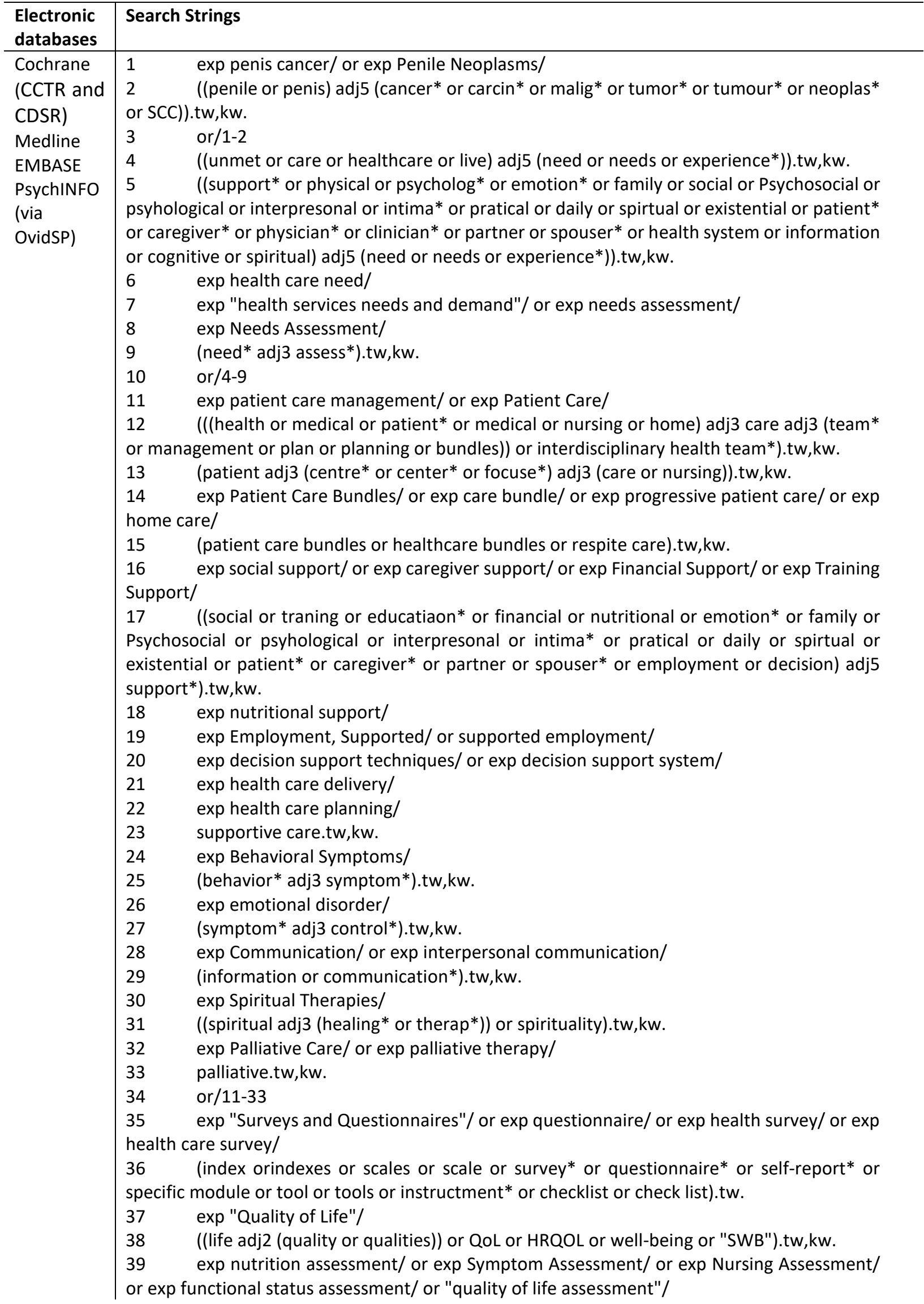




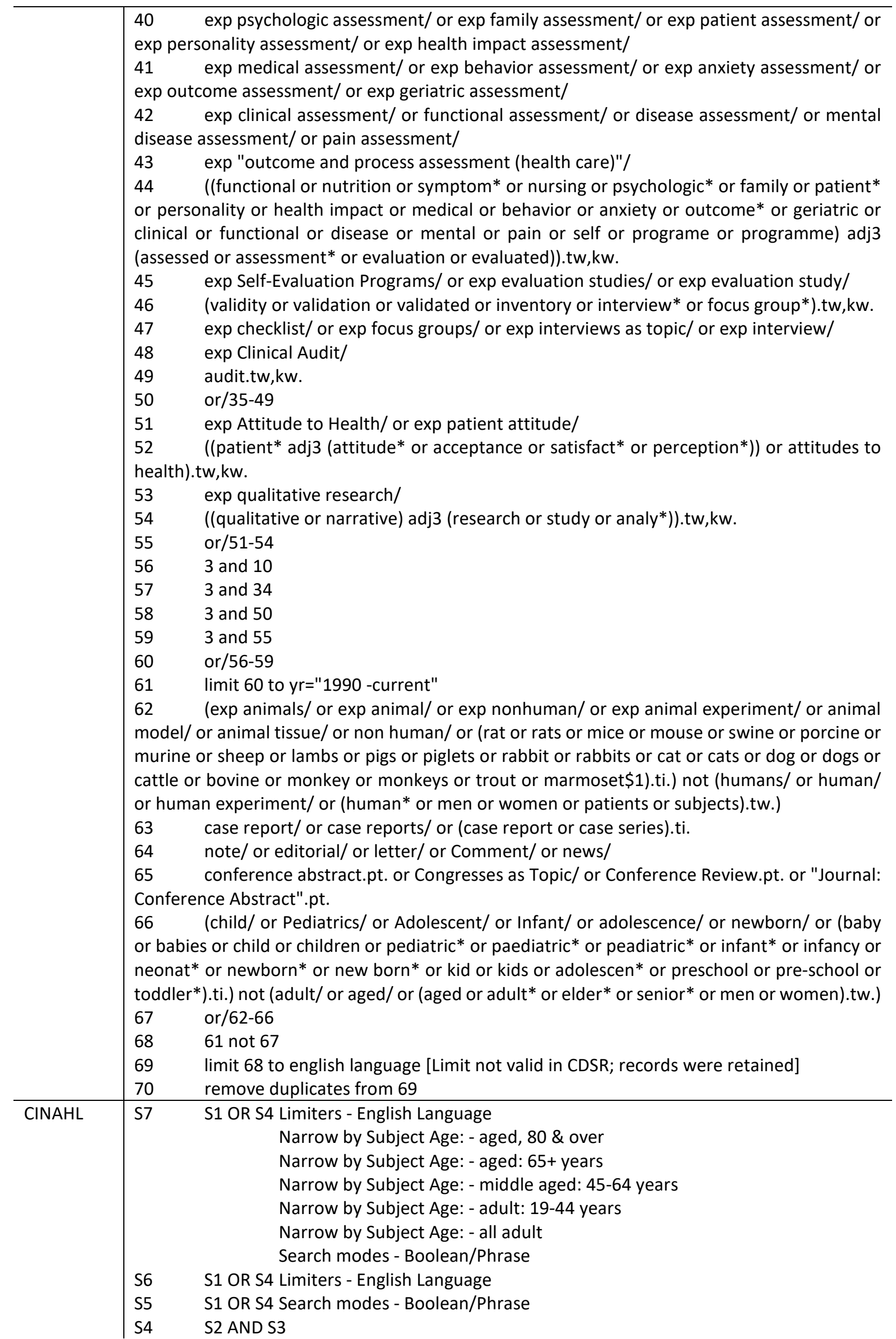


S3 TI ( cancer* or carcin* or malig* or tumor* or tumour* or neoplas* or SCC ) OR AB ( cancer* or carcin* or malig* or tumor* or tumour* or neoplas* or SCC )

S2 TI (penile or penis) OR AB (penile or penis )

S1 (MH "Penile Neoplasms") 


\begin{tabular}{|c|c|c|c|c|c|}
\hline \multicolumn{2}{|c|}{ Criteria } & $\begin{array}{c}\text { Yes } \\
\text { (2/good) }\end{array}$ & $\begin{array}{l}\text { Partial } \\
\text { (1/fair) }\end{array}$ & $\begin{array}{c}\text { No } \\
\text { (0/poor) }\end{array}$ & score \\
\hline \multicolumn{5}{|c|}{ Study aims \& context } & \\
\hline 1. & $\begin{array}{l}\text { Is the research question } \\
\text { sufficiently described? }\end{array}$ & $\begin{array}{l}\text { Research question clearly } \\
\text { identified by the end of the } \\
\text { research process, if not at the } \\
\text { outset. }\end{array}$ & $\begin{array}{l}\text { Research question or } \\
\text { objective is } \\
\text { vaguely/incompletely } \\
\text { reported. }\end{array}$ & $\begin{array}{l}\text { Question or objective is } \\
\text { not reported, or is } \\
\text { incomprehensible. }\end{array}$ & \\
\hline 2. & $\begin{array}{l}\text { Is qualitative method } \\
\text { appropriate? }\end{array}$ & $\begin{array}{l}\text { Qualitative method is } \\
\text { appropriate for the aims and } \\
\text { the qualitative framework is } \\
\text { identified and justified. }\end{array}$ & $\begin{array}{l}\text { Qualitative method } \\
\text { appropriate but the } \\
\text { methodological } \\
\text { framework unclear or } \\
\text { not adequately justified. }\end{array}$ & $\begin{array}{l}\text { Qualitative methods } \\
\text { inappropriate for the } \\
\text { aims. }\end{array}$ & \\
\hline 3. & $\begin{array}{l}\text { Is the *setting/context } \\
\text { clearly described? }\end{array}$ & $\begin{array}{l}\text { *Context/setting is clearly } \\
\text { described, permitting the } \\
\text { reader to relate the findings } \\
\text { to other settings. }\end{array}$ & $\begin{array}{l}\text { The context/setting is } \\
\text { partially described. }\end{array}$ & $\begin{array}{l}\text { The context/setting is } \\
\text { not described. }\end{array}$ & \\
\hline \multicolumn{5}{|c|}{ Sampling } & \\
\hline 4. & $\begin{array}{l}\text { Is the sampling strategy } \\
\text { clearly described? }\end{array}$ & $\begin{array}{c}\text { Sampling strategy \& rationale } \\
\text { clearly described and } \\
\text { justified. }\end{array}$ & $\begin{array}{l}\text { Sampling strategy not } \\
\text { clearly described or is } \\
\text { not fully justified. }\end{array}$ & $\begin{array}{l}\text { Sampling not } \\
\text { described. }\end{array}$ & \\
\hline 5. & $\begin{array}{l}\text { Is sampling method likely } \\
\text { to recruit all relevant } \\
\text { cases? (purposive, } \\
\text { theoretical sampling) }\end{array}$ & $\begin{array}{l}\text { Sample includes the full } \\
\text { range of relevant, possible } \\
\text { cases (more than simple } \\
\text { convenience sample) } \\
\text { permitting conceptual (rather } \\
\text { than statistical) } \\
\text { generalisations. }\end{array}$ & $\begin{array}{l}\text { Sampling was purposive } \\
\text { but does not include the } \\
\text { full range of possible } \\
\text { cases. }\end{array}$ & $\begin{array}{l}\text { No attempt made to } \\
\text { sample purposively or } \\
\text { theoretically, or } \\
\text { sampling strategy not } \\
\text { described. }\end{array}$ & \\
\hline 6. & $\begin{array}{l}\text { Are relevant } \\
\text { characteristics of sample } \\
\text { given? }\end{array}$ & $\begin{array}{l}\text { Relevant details of the } \\
\text { characteristics of sample } \\
\text { given. }\end{array}$ & $\begin{array}{l}\text { Incomplete details of } \\
\text { sample characteristics } \\
\text { given. }\end{array}$ & $\begin{array}{l}\text { No details of sample } \\
\text { characteristics given. }\end{array}$ & \\
\hline 7. & $\begin{array}{l}\text { Is rationale for sample } \\
\text { size (e.g data saturation) } \\
\text { given? }\end{array}$ & $\begin{array}{c}\text { Gives rationale for } \\
\text { termination of data collection } \\
\text { e.g. data saturation. }\end{array}$ & $\begin{array}{c}\text { Reasons for sample size } \\
\text { implied or no firm } \\
\text { rationale. }\end{array}$ & $\begin{array}{l}\text { No reason given for } \\
\text { sample size. }\end{array}$ & \\
\hline \multicolumn{5}{|c|}{ Data collection } & \\
\hline 8. & $\begin{array}{l}\text { Are method of data } \\
\text { collection clearly } \\
\text { described? }\end{array}$ & $\begin{array}{l}\text { Data collection methods are } \\
\text { systematic and clearly } \\
\text { described allowing an audit } \\
\text { trail such that procedures } \\
\text { could be replicated. }\end{array}$ & $\begin{array}{l}\text { Data collection methods } \\
\text { not clearly described. } \\
\text { Difficult to determine if } \\
\text { systematic or replicable. }\end{array}$ & $\begin{array}{l}\text { Data collection } \\
\text { procedures are not } \\
\text { described. }\end{array}$ & \\
\hline 9. & $\begin{array}{l}\text { Is method of data } \\
\text { collection appropriate } \\
\text { for research question } \\
\text { and paradigm? }\end{array}$ & $\begin{array}{l}\text { Data collection methods are } \\
\text { appropriate for the research } \\
\text { aims and the methodological } \\
\text { and analytical framework. }\end{array}$ & $\begin{array}{c}\text { The appropriateness of } \\
\text { data collection methods } \\
\text { are unclear. }\end{array}$ & $\begin{array}{l}\text { Data collection } \\
\text { inappropriate for the } \\
\text { aims and } \\
\text { methodological } \\
\text { framework. }\end{array}$ & \\
\hline 10 & $\begin{array}{l}\text { Has the researcher } \\
\text { verified the data } \\
\text { (e.g. by triangulation)? }\end{array}$ & $\begin{array}{l}\text { More than one method of } \\
\text { data collection carried out or } \\
\text { more than one analyst } \\
\text { involved, or other methods of } \\
\text { verification employed (e.g. } \\
\text { member checking or line of } \\
\text { questioning during } \\
\text { interview). }\end{array}$ & $\begin{array}{l}\text { Unclear whether } \\
\text { triangulation or other } \\
\text { types of verification } \\
\text { used. }\end{array}$ & $\begin{array}{l}\text { No triangulation or } \\
\text { other methods of } \\
\text { verification described. }\end{array}$ & \\
\hline
\end{tabular}




\begin{tabular}{|c|c|c|c|c|c|}
\hline \multicolumn{5}{|c|}{ Data analysis } & \multirow[t]{2}{*}{ Score } \\
\hline 11 & $\begin{array}{l}\text { Are data analysis } \\
\text { methods clearly } \\
\text { described? }\end{array}$ & $\begin{array}{l}\text { Systematic analytic method } \\
\text { clearly described such that } \\
\text { procedures could be } \\
\text { replicated. }\end{array}$ & $\begin{array}{l}\text { Analytic methods not } \\
\text { clearly described. }\end{array}$ & $\begin{array}{l}\text { Analytic methods not } \\
\text { described. }\end{array}$ & \\
\hline
\end{tabular}

\begin{tabular}{|c|c|c|c|c|}
\hline \multicolumn{2}{|c|}{ Criteria } & \multirow{2}{*}{$\begin{array}{c}\text { Yes } \\
\text { (2/good) } \\
\text { Analytic methods seem } \\
\text { appropriate \& are well- } \\
\text { described. }\end{array}$} & \multirow{2}{*}{$\begin{array}{c}\text { Partial } \\
(\mathbf{1 / f a i r )} \\
\text { Analytic methods only } \\
\text { partially described and/or } \\
\text { some concerns about } \\
\text { appropriateness. }\end{array}$} & \multirow{2}{*}{$\begin{array}{c}\text { No } \\
\text { (0/poor) } \\
\text { Analytic methods not } \\
\text { described and/or } \\
\text { appropriate. }\end{array}$} \\
\hline 12 & $\begin{array}{l}\text { Are data analysis } \\
\text { methods appropriate? }\end{array}$ & & & \\
\hline 13 & $\begin{array}{l}\text { Are competing } \\
\text { accounts/deviant data } \\
\text { taken into account? }\end{array}$ & $\begin{array}{c}\text { Account given of negative } \\
\text { or deviant cases in the } \\
\text { analysis. }\end{array}$ & $\begin{array}{l}\text { Analysis of deviant or negative } \\
\text { cases not clearly described. }\end{array}$ & $\begin{array}{c}\text { No account given of } \\
\text { negative or deviant } \\
\text { cases. }\end{array}$ \\
\hline \multicolumn{5}{|c|}{ Reflexivity } \\
\hline 14 & $\begin{array}{l}\text { To what extent is the } \\
\text { researcher reflective? }\end{array}$ & $\begin{array}{l}\text { The researcher explicitly } \\
\text { assessed the likely impact } \\
\text { of their own personal } \\
\text { characteristics and the } \\
\text { methods used on the } \\
\text { data obtained. }\end{array}$ & $\begin{array}{l}\text { Possible sources of influence } \\
\text { on the data obtained were } \\
\text { mentioned, but the likely } \\
\text { impact of the influence was } \\
\text { not discussed. }\end{array}$ & $\begin{array}{l}\text { No evidence of } \\
\text { reflexivity in the report. }\end{array}$ \\
\hline \multicolumn{5}{|c|}{ Conclusions } \\
\hline 15 & $\begin{array}{l}\text { Are the interpretations } \\
\text { and conclusions } \\
\text { supported by the data? }\end{array}$ & $\begin{array}{l}\text { The interpretations are } \\
\text { clearly described and } \\
\text { supported by the data } \\
\text { and are evidenced by } \\
\text { sufficient participant } \\
\text { quotes. }\end{array}$ & $\begin{array}{l}\text { The conclusions are unclear or } \\
\text { only partially supported by } \\
\text { the data, or there is } \\
\text { insufficient raw data to } \\
\text { support conclusions. }\end{array}$ & $\begin{array}{c}\text { Conclusions are not } \\
\text { identified or are felt } \\
\text { not to be supported by } \\
\text { the data or conclusions } \\
\text { are absent. }\end{array}$ \\
\hline
\end{tabular}


Quantitative quality assessment checklist

\section{Quality Assessment Quantitative Studies}

\begin{tabular}{|c|c|c|c|c|c|c|}
\hline \multicolumn{2}{|c|}{ Criteria } & $\begin{array}{c}\text { Yes } \\
\text { (2/good) }\end{array}$ & $\begin{array}{l}\text { Partial } \\
\text { (1/fair) }\end{array}$ & $\begin{array}{c}\text { No } \\
\text { (0/poor) }\end{array}$ & N/A & Score \\
\hline \multicolumn{7}{|c|}{ Study aims } \\
\hline 1. & $\begin{array}{l}\text { Is the } \\
\text { hypothesis/aim/objecti } \\
\text { ve of the study clearly } \\
\& \text { sufficiently } \\
\text { described? }\end{array}$ & $\begin{array}{l}\text { Easily identified in } \\
\text { introduction/method. } \\
\text { Specifies: purpose, } \\
\text { subjects/target population, } \\
\text { and specific interventions/ } \\
\text { associations under } \\
\text { investigation. }\end{array}$ & $\begin{array}{c}\text { Vague/incomplete reporting or some info } \\
\text { has to be gathered from parts of the paper } \\
\text { other than intro/background/ } \\
\text { objective section. }\end{array}$ & $\begin{array}{l}\text { Question or objective not } \\
\text { reported/ } \\
\text { incomprehensible. }\end{array}$ & & \\
\hline \multicolumn{7}{|c|}{ Study design \& sample characteristics } \\
\hline 2. & $\begin{array}{l}\text { Is the study design well } \\
\text { described \& } \\
\text { appropriate? } \\
\text { (If study question not } \\
\text { given, infer from } \\
\text { conclusions). }\end{array}$ & $\begin{array}{l}\text { Design easily identified, well } \\
\text { described and appropriate. }\end{array}$ & $\begin{array}{l}\text { Design and/or study question not clearly } \\
\text { described, or design only partially } \\
\text { addresses study question. }\end{array}$ & $\begin{array}{l}\text { Design does not answer } \\
\text { study question or design is } \\
\text { poorly described. }\end{array}$ & & \\
\hline 3. & $\begin{array}{l}\text { Is the method of } \\
\text { patient/control group } \\
\text { selection described } \\
\text { and appropriate? }\end{array}$ & $\begin{array}{l}\text { Described and appropriate. } \\
\text { Inclusion/exclusion criteria } \\
\text { described and defined. }\end{array}$ & $\begin{array}{l}\text { Selection methods (and } \\
\text { inclusion/exclusion criteria) not } \\
\text { completely described, but no obvious } \\
\text { inappropriateness. Or selection strategy } \\
\text { likely introduces bias but not enough to } \\
\text { seriously distort results. }\end{array}$ & $\begin{array}{l}\text { No information/ } \\
\text { inappropriate information } \\
\text { provided or selection bias } \\
\text { which likely distorts } \\
\text { results. }\end{array}$ & & \\
\hline 4. & $\begin{array}{l}\text { Are the characteristics } \\
\text { of patient/control } \\
\text { group(s) clearly } \\
\text { described (i.e. age } \\
\text { range, health } \\
\text { characteristic/s)? }\end{array}$ & $\begin{array}{c}\text { Sufficient relevant } \\
\text { demographic information. } \\
\text { Reproducible criteria used to } \\
\text { categorise participants } \\
\text { clearly defined. }\end{array}$ & $\begin{array}{l}\text { Poorly defined criteria or incomplete } \\
\text { demographic information. }\end{array}$ & $\begin{array}{l}\text { No baseline/demographic } \\
\text { info provided. }\end{array}$ & & \\
\hline 5. & $\begin{array}{l}\text { Were } \\
\text { patients/participants } \\
\text { randomised to } \\
\text { intervention groups? }\end{array}$ & $\begin{array}{l}\text { If randomisation appropriate: } \\
\text { Evidence of randomisation } \\
\text { with a description of the } \\
\text { method used (e.g. random } \\
\text { number tables, block design). }\end{array}$ & $\begin{array}{l}\text { Randomisation mentioned but method is } \\
\text { not (i.e. may be possible that } \\
\text { randomisation not true). }\end{array}$ & $\begin{array}{l}\text { Random allocation not } \\
\text { mentioned although it } \\
\text { would have been feasible } \\
\text { and appropriate (and } \\
\text { possible done). }\end{array}$ & $\begin{array}{l}\text { Study has no control } \\
\text { group i.e. } \\
\text { observational/ } \\
\text { surveys/case-control. } \\
\text { Or adequate } \\
\text { justification for non } \\
\text { randomisation. given. }\end{array}$ & \\
\hline
\end{tabular}


randomisation/allocati on concealed from patients?
Evidence the next allocation was concealed from both parties

(recruiter and patient/carer) at the point of consent

(e.g. remote randomisation)
Allocation concealment reported but not described.
Allocation concealment would have been possible (and was possibly done) but not reported.

concealment not

possible due to study design (e.g. cluster randomised trial)

No information or losses Losses adequately reported \& not likely to affect results.

Losses not well reported, but small \& of patients lost to

7. follow-up been described?

8. $\quad$ Are intervention(s) clearly described?

9. $\quad$ Are the main outcomes to be measured clearly described in the introduction/method?

Defined and reproducible. not likely to affect results.

large and likely to affect results.

Partially defined, but insufficient detail to reproduce design.

Defined and measured according to reproducible criteria.

Definition leaves room for subjectivity, or not sure (i.e. not reported in detail, but probably acceptable). Or precise definition(s) are missing, but no evidence of major problems. Or instrument/mode of assessment(s) not reported.

10 If possible, was an Assessor blind to attempt made to blind those measuring the main outcomes of the intervention?

11 Are population characteristics (if measured \& described) controlled for and adequately described? intervention/study group.

Inadequate blinding: i.e. assessor may have been aware of group participant assigned to.

attempt made to blind assessor. mentioned in results section.

Or measures not

defined/inconsistent/ poorly defined. follow-up.

Not possible/ appropriate - e.g. observational

Incomplete control/

Appropriate control at design/analysis stage or randomised study with description. Or not considered but unlikely to seriously influence comparable baseline results. characteristics.

2 Are the main findings clearly described?

Simple outcome data (e.g. mean/prevalence) reported for all major findings.

13 Are methods of analysis $\quad$ Described and appropriate.
adequately described

Described and appropriate.

(nt

teported but probably

appropriate or some tests 


\begin{tabular}{|c|c|c|c|c|c|}
\hline & and appropriate? & & appropriate, some not. & & \\
\hline 14 & $\begin{array}{l}\text { Are estimates of } \\
\text { variance reported for } \\
\text { the main results? }\end{array}$ & $\begin{array}{l}\text { Appropriate estimates provided } \\
\text { (SD/SE, confidence intervals). }\end{array}$ & $\begin{array}{l}\text { Undefined or estimates provided for } \\
\text { some but not all outcomes. }\end{array}$ & No information. & \\
\hline 15 & $\begin{array}{l}\text { In trials/cohort studies, } \\
\text { do analyses adjust for } \\
\text { different lengths of } \\
\text { follow-up, or in case- } \\
\text { control studies, is the } \\
\text { time between } \\
\text { intervention and } \\
\text { outcome the same for } \\
\text { cases/controls? }\end{array}$ & $\begin{array}{l}\text { Different lengths of follow-up } \\
\text { adjusted for (e.g. survival } \\
\text { analysis) and adequately } \\
\text { described. }\end{array}$ & $\begin{array}{l}\text { Different lengths of follow-up } \\
\text { probably adjusted for but not } \\
\text { adequately described. }\end{array}$ & $\begin{array}{l}\text { Differences in follow-up } \\
\text { ignored. }\end{array}$ & $\begin{array}{l}\text { Cross-sectional design } \\
\text { or same length of } \\
\text { follow-up. }\end{array}$ \\
\hline
\end{tabular}

\begin{tabular}{|c|c|c|c|c|c|}
\hline 16 & $\begin{array}{l}\text { If appropriate, were } \\
\text { data analysed } \\
\text { according to ITT } \\
\text { (intention to treat) } \\
\text { principle? }\end{array}$ & $\begin{array}{c}\text { All participant data } \\
\text { analysed regardless of } \\
\text { adherence to protocol or } \\
\text { continuation in trial. }\end{array}$ & $\begin{array}{l}\text { Attempt made to analyse data according } \\
\text { to ITT principle, but inappropriate method } \\
\text { or some participants not included. }\end{array}$ & $\begin{array}{l}\text { No attempt made to carry } \\
\text { out ITT analysis. }\end{array}$ & $\begin{array}{c}\text { Design not } \\
\text { appropriate for ITT } \\
\text { (e.g. cross-sectional } \\
\text { data). }\end{array}$ \\
\hline 17 & $\begin{array}{l}\text { Are the conclusions } \\
\text { supported by the } \\
\text { results? }\end{array}$ & $\begin{array}{l}\text { All conclusions supported } \\
\text { by data. }\end{array}$ & $\begin{array}{l}\text { Some of the major conclusions are } \\
\text { supported by the data; some are not. Or } \\
\text { speculative interpretations are not } \\
\text { indicated as such. }\end{array}$ & $\begin{array}{c}\text { None/few of major } \\
\text { conclusions supported by the } \\
\text { data. }\end{array}$ & \\
\hline
\end{tabular}

SHAW, C., MCNAMARA, R., ABRAMS, K., CANNINGS-JOHN, R. L., HOOD, K., LONGO, M., MYLES, S., O'MAHONY, M. S., ROE, B. \& WILLIAMS, K. 2009. Systematic review of respite care in the frail elderly. Health Technology Assessment, 13, 1-246. 
Supplementary 3 Clinical and demographic characteristics of the included participants

\begin{tabular}{|c|c|c|c|c|c|c|}
\hline Author and Year & Age (years) & Marital status & Ethnicity & Education level & Cancer stage & Treatment \\
\hline Bhat et al., 2018 & $\begin{array}{l}\text { Median 51.8 (38-74) Partners } \\
\text { median 37.9 (26-55) }\end{array}$ & Not reported & Not reported & Not reported & Not reported & $\mathrm{n} 2$ total penectomy; $\mathrm{n} 10$ partial penectomy \\
\hline $\begin{array}{l}\text { Bullen et al., 2009: } \\
\text { reporting same study as } \\
\text { Bullen et al., } 2010\end{array}$ & Median 62.5 (50-76) & $\begin{array}{l}\text { n7 married, n1 single, n1 } \\
\text { separated }\end{array}$ & Not reported & Not reported & Not reported & $\mathrm{n} 7$ total penectomy; $\mathrm{n} 2$ partial penectomy \\
\hline D'Ancona et al., 1997 & median 50.5 (37-70) & $\begin{array}{l}\text { All married and living with their } \\
\text { partners. }\end{array}$ & Not reported & $\begin{array}{l}\text { Average schooling } 2.8 \text { years } \\
\text { (median } 3 \text { years). } n=4 \text { patients } \\
\text { were illiterate, } \mathrm{n}=1<4 \mathrm{y} \\
\text { schooling }\end{array}$ & T1 $n=1 ;$ T2 n=8; T3 n=5 & $\begin{array}{l}\text { Radical or modified lymphadenectomy was } \\
\text { performed in } n 11 \text {. N3 treatment modality missing. } \\
\text { No further date reported. }\end{array}$ \\
\hline Drager et al., 2017 & $\begin{array}{ll}\text { Mean } 64 \text { (SD 13.6, 31-88) } \\
\end{array}$ & Not reported & Not reported & Not reported & Not reported & $\begin{array}{l}\text { Partial penectomy } \mathrm{n} 28 \text {, total penectomy } \mathrm{n} 1 \text {, } \\
\text { chemotherapy } \mathrm{n} 11\end{array}$ \\
\hline Dulaunay et al., 2014 & $\begin{array}{l}\text { Mean } 73.2 \text { (SD not reported, 45- } \\
\text { 89) }\end{array}$ & n19 married or in a couple & Not reported & Not reported & Not reported. & n19 penile brachytherapy \\
\hline Ficarra et al., 2000 & Mean 63.0 (SD not reported) & Not reported & Not reported & Not reported & Not reported & n16 Partial penectomy \\
\hline Gordan et al., 2017 & Mean 62.2 (SD 10.9, 41-85) & $\begin{array}{l}\text { Married } \mathrm{n} 9 \text {, separated } \mathrm{n} 1 \text {, } \\
\text { widowed } \mathrm{n} \text {, divorced } \mathrm{n} 1 \text {. }\end{array}$ & $\begin{array}{l}39 \% \text { white, } 15 \% \text { Asian, } \\
15 \% \text { Black, 31\% Hispanic }\end{array}$ & $\begin{array}{l}\text { 62\% High School, 38\% University } \\
\text { Degree }\end{array}$ & Not reported & $\begin{array}{l}\text { n10 partial penectomy, n2 excision, n1 total } \\
\text { penectomy }\end{array}$ \\
\hline Kieffer et al., 2014 & $\begin{array}{l}\text { n54 penile sparing surgery } 61.8 \\
\text { (SD 12.4); n36 partial penectomy } \\
70.9 \text { (SD 8.7), p<0.001 }\end{array}$ & Married $\mathrm{n} 75$, single $n 15$ & $86 \%$ Caucasian & $\begin{array}{l}\text { Primary/middle school n7 (7.8\%), } \\
\text { Occuupational high school n38 } \\
\text { (42.2\%), College preparatory } \\
\text { high school n8 (8.9\%), college } \\
\text { University n37 (41.1\%) }\end{array}$ & Not reported. & $\begin{array}{l}\text { Penile sparing } \mathrm{n} 54 \text {, partial penectomy } \mathrm{n} 36, \\
\text { lymphadenectomy } \mathrm{n} 25 \text {, no further treatment data } \\
\text { reported. }\end{array}$ \\
\hline Mortensen et al., 2013 & Mean 58.5 (SD not reported) & $\begin{array}{l}n 1 \text { married, } n 2 \text { in a relationship } \\
\text { and } n 1 \text { single. }\end{array}$ & Not reported & Not reported & Not reported & n2 glansectomy, n2 partial penectomy \\
\hline Opjordsmoen et al., 1994 & Mean 57 years, (range 28-75) & 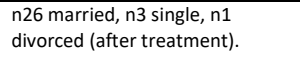 & Not reported & Not reported & $\begin{array}{l}\text { Tis: n3, Tis } 1 \mathrm{n} 22, \text { Tis } 2 \mathrm{n} 2 \text {, Tis } 3 \mathrm{n} 1 \text {, Tis } 4 \\
\mathrm{n} 1 \text {, Tis } \mathrm{X} \text { n1. N category: N0 n26, N1-2 n4. }\end{array}$ & $\begin{array}{l}\text { Local incision/laser beam } \mathrm{n} 5 \text {, radiotherapy } \mathrm{n} 12 \text {, } \\
\text { partial penectomy } \mathrm{ng} \text {, total penectomy } \mathrm{n} 4 \text {. }\end{array}$ \\
\hline Skeppner et al., 2015 & $\begin{array}{l}\text { Mean } 60 \text { (range 37-73) and } \\
\text { partners mean } 57 \text { years (range } \\
\text { 30-72) }\end{array}$ & $\begin{array}{l}\text { All in a steady relationship } \\
\text { (median relationship time } 29 \text { (1- } \\
\text { 54) years }\end{array}$ & Not reported & Not reported & pT1 n12, and G2 n14, n2 missing data & $\begin{array}{l}\text { n26 organ sparing laser treatment of the penis, n2 } \\
\text { laser treatment and total penectomy. }\end{array}$ \\
\hline Skeppner et al., 2008 & Median 63.5 (range 34-90). & $\begin{array}{l}\text { Married } n=34 \text {, Single with a } \\
\text { steady partner }(n 2) \text {, single } n=10 .\end{array}$ & Not reported & Not reported & $\begin{array}{l}\text { CIS n13, T1 n14, T2 n19. } \\
\text { Tumor grade: Ca in situ n16, G1 n=6, G2 } \\
\text { n12, G3 n2. }\end{array}$ & $\begin{array}{l}\text { Lymph node dissection n16, chemotherapy n1, } \\
\text { radiotherapy n1, relapse n8. No further data } \\
\text { reported. }\end{array}$ \\
\hline Soh et al., 2014 & $\begin{array}{l}\text { n19 patients } 73.2 \text { (SD 11.7); } \\
\text { control (n19) controls 70.0 (SD } \\
10.5), p<.0381\end{array}$ & $\begin{array}{l}\text { Patients in couple (n19); Control } \\
\text { in couple (n16), single (n3), p<.05 }\end{array}$ & $\begin{array}{l}\text { All participants } \\
\text { Caucasian }\end{array}$ & Not reported. & $\begin{array}{l}\text { n19 patients T1 well differentiated } \\
\text { tumour <20mm, no lymph nodes; (n19) } \\
\text { controls no diagnosis of cancer }\end{array}$ & n19 Low dose rate PB with Iridium-192 \\
\hline Sosnowskie et al., 2016 & 60 years, 35 to 74 years & Married $60 \%$; single $40 \%$ & Not reported. & $\begin{array}{l}\text { Education basic } \mathrm{n} 5(50 \%) \text {; higher } \\
\text { education } \mathrm{n} 5 \text { (50\%), no further } \\
\text { classifications reported. }\end{array}$ & pT1b n4; pT2 n3; pT3 n3; & n10 total penectomy \\
\hline Wan et al., 2018 & $\begin{array}{l}n 7 \text { (wide local excisions) } 60.7 \text { (SD } \\
10,45-72 \text { ); } n 8 \text { (partial } \\
\text { penectomy) } 62 \text { (SD 9.7, 44-74 } \\
\text { years), P>.05 }\end{array}$ & n15 married (100\%) & Not reported. & Not reported. & n3 Tis; n1 Ta; n8 T1; n3 T2 & n7 wide local excisions; $\mathrm{n} 8$ partial penectomies \\
\hline Windahl et al., 2004 & Not reported. & $\begin{array}{l}\text { n31 in relationship; } n 10 \text { single at } \\
\text { time of study }\end{array}$ & Not reported. & Not reported. & $\begin{array}{l}\text { Tis-T2, GI-II tumours less } 3 \mathrm{~cm} \text { in } \\
\text { diameter. No further details reported. }\end{array}$ & n31 men treated by laser therapy \\
\hline Witty et al., 2013 & $\begin{array}{l}63 \text { years (range } 41-82 \text { years) at } \\
\text { diagnosis and } 67 \text { (range } 48-83 \\
\text { years) at time of interview. }\end{array}$ & $\begin{array}{l}\text { n17 married/relationship; n11 } \\
\text { single }\end{array}$ & n27 white; n1 asian & Not reported. & Not reported. & $\begin{array}{l}\text { All men treated by surgical intervention ranging from } \\
\text { circumcision to total penectomy. Not specific details } \\
\text { reported. }\end{array}$ \\
\hline
\end{tabular}

